Original paper

\title{
Oxide minerals in the granitic cupola of the Jálama Batholith, Salamanca, Spain. Part II: Sn, W and Ti minerals in intra-granitic quartz veins
}

\author{
Teresa LLORENS*, María Candelas MORO \\ Department of Geology, University of Salamanca, Plaza de los Caidos s/n, 37006 Salamanca, Spain; tllg@usal.es \\ * Corresponding author
}

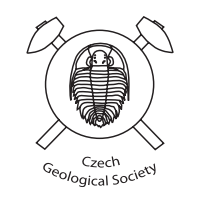

The mineralized quartz veins hosted by the distal granitic facies of the Jálama Batholith were generated by successive processes of the fractures opening and filling by hydrothermal fluids enriched in volatiles. Cassiterite I, wolframite I and rutile I crystallized during an early stage, followed - after a ductile deformation - by a main Fe-Zn sulphide deposition, composed initially by subordinate cassiterite II and wolframite II. Later during this main sulphide deposition, ixiolite and $\mathrm{Nb}$-Ta-rich rutile II filled fractures. Finally, the late open spaces and cavities were sealed by quartz and carbonates.

The crystallization of wolframite II indicates enrichment in Mn of the fluid, compared with wolframite I, suggesting a normal evolutionary trend from the early $\mathrm{Sn}-\mathrm{W}$ deposition to the first stage of the main Fe-Zn sulphide precipitation in the quartz veins. The scarcity of Sn during the latest stages of the ore deposition prevented the crystallization of cassiterite, favoring instead the incorporation of this element into the ixiolite and rutile II structure. This hydrothermal evolution from the crystallization of wolframite II to ixiolite and rutile II responded to enrichment in $\mathrm{Ti}$ and $\mathrm{Fe}$ of the late fluid, thus favoring a partially reversed trend in the $\mathrm{Nb}-\mathrm{Ta}-\mathrm{Ti}$ oxides composition. The late enrichment in $\mathrm{Ti}$ and Fe of the hydrothermal fluid could be explained by contamination by external metamorphic and/or meteoric fluids enriched in these elements. The incorporation of $\mathrm{Ti}, \mathrm{Nb}$ and $\mathrm{Ta}$ into the ixiolite and rutile structure was favored by high $\mathrm{F}$ concentrations in the hydrothermal fluids, inherited from the residual melts of the Jálama Batholith.

Keywords: Jálama Batholith, quartz veins, cassiterite, wolframite, rutile, ixiolite

Received: 7 February 2012; accepted: 21 August 2012; handling editor: M. Novák

\section{Introduction}

Cassiterite and wolframite represent the most common $\mathrm{Sn}$ and $\mathrm{W}$ minerals related to S-type granites, and thus have been studied extensively (e.g. Černý et al. 1985; Gouanvic and Babkine 1985; Giuliani 1987; Černý and Ercit 1989; Neiva 1996, 2008; Haapala 1997; Lerouge et al. 2007; Pal et al. 2007). Additionally, Nb-Ta oxide minerals containing variable amounts of $\mathrm{W}$ are common in this type of rare-metal granites and related granitic pegmatites (e.g. Černý and Ercit 1985, 1989 and references therein; Johan and Johan 1994; Tindle et al. 1998; Černý and Chapman 2001; Auriscchio et al. 2002; Breiter et al. 2007; Černý et al. 2007a; Beurlen et al. 2008; Novák et al. 2008; Martins et al. 2011; René and Škoda 2011). These pegmatite bodies generally belong to the LCT family of Černý and Ercit (2005). In contrast, much less attention has been paid to the $\mathrm{Nb}$ - $\mathrm{Ta}$ oxide minerals in hydrothermal quartz veins with cassiterite and/or wolframite (Amichba and Dubakina 1974; Beddoe-Stephens and Fortey 1981; Tindle and Webb 1989; Neiva 1996).

The Jálama Batholith in the Navasfrías District in the central part of the Iberian Massif (Fig. 1) is a great example having a representation of all these mineralization types. It has been well known for decades for its peri-batholithic pegmatite dikes and intra-granitic quartz veins that were mined for cassiterite and/or wolframite (Fernández-Leyva 2007; Llorens 2011). The mining district is formed by the Cadalso-Casillas de Flores Batholith and the Jálama Batholith granitic cupola. Recent contributions showed the broad mineralogical and chemical variability of these deposits, which is not restricted to the $\mathrm{Sn}$ and $\mathrm{W}$ ores. For example, abundant $\mathrm{Fe}-$, $\mathrm{Mn}-, \mathrm{Sr}-, \mathrm{Li}-, \mathrm{Ca}-$ and $\mathrm{Mg}$-bearing phosphates have been documented from the granites, the pegmatite dikes and the mineralized quartz veins (Llorens and Moro 2007, 2008, 2012a; Moro and Llorens 2008). These phosphates have been useful for determining the magmatic, hydrothermal and supergene evolution of the Jálama Batholith. Additionally, the granitic pegmatites host important amounts of columbite- and pyrochlore-group minerals (Llorens and Moro 2010a, b, c), whereas rutile enriched in $\mathrm{Nb}$ and Ta and ixiolite with high $\mathrm{W}$ and Ti contents have been identified in the mineralized quartz veins.

This contribution aims to complement the characterization of the $\mathrm{Sn}-\mathrm{W}-\mathrm{Nb}-\mathrm{Ta}-\mathrm{Ti}$ mineralization related to the Jálama Batholith, which was introduced in Part I (Llorens and Moro 2012b), with a study of the granitic 
facies and the pegmatite dikes. Thus, the main objectives are: 1) to identify the different episodes of mineralization in the quartz veins, 2) to characterize texturally, mineralogically and chemically $\mathrm{Sn}-\mathrm{W}-\mathrm{Nb}-\mathrm{Ta}-\mathrm{Ti}$ minerals of each episode, 3) to describe the substitution mechanisms and zoning patterns of these minerals, 4) to define the chemical evolution of the $\mathrm{Sn}-\mathrm{W}-\mathrm{Nb}-\mathrm{Ta}-\mathrm{Ti}$ minerals in the quartz veins through their textural relationships and compositional variations, and, finally, 5) to determine the role of volatiles in the formation of this deposit.

\section{Geological setting}

The Jálama Batholith intruded the pre-Ordovician greywacke-pelite metasediments of the Schist-Greywacke Complex Domain (CEG) in the middle-western Iberian Peninsula (Martínez Catalán et al. 2004), after the main Variscan deformational phases ( 300 Ma, Ramírez 1996). The External Unit of the Jálama Batholith (Ramírez 1996; Ramírez and Grundvig 2000) hosts the main tin-tungsten deposits of the Navasfrías district (geographic coordinates
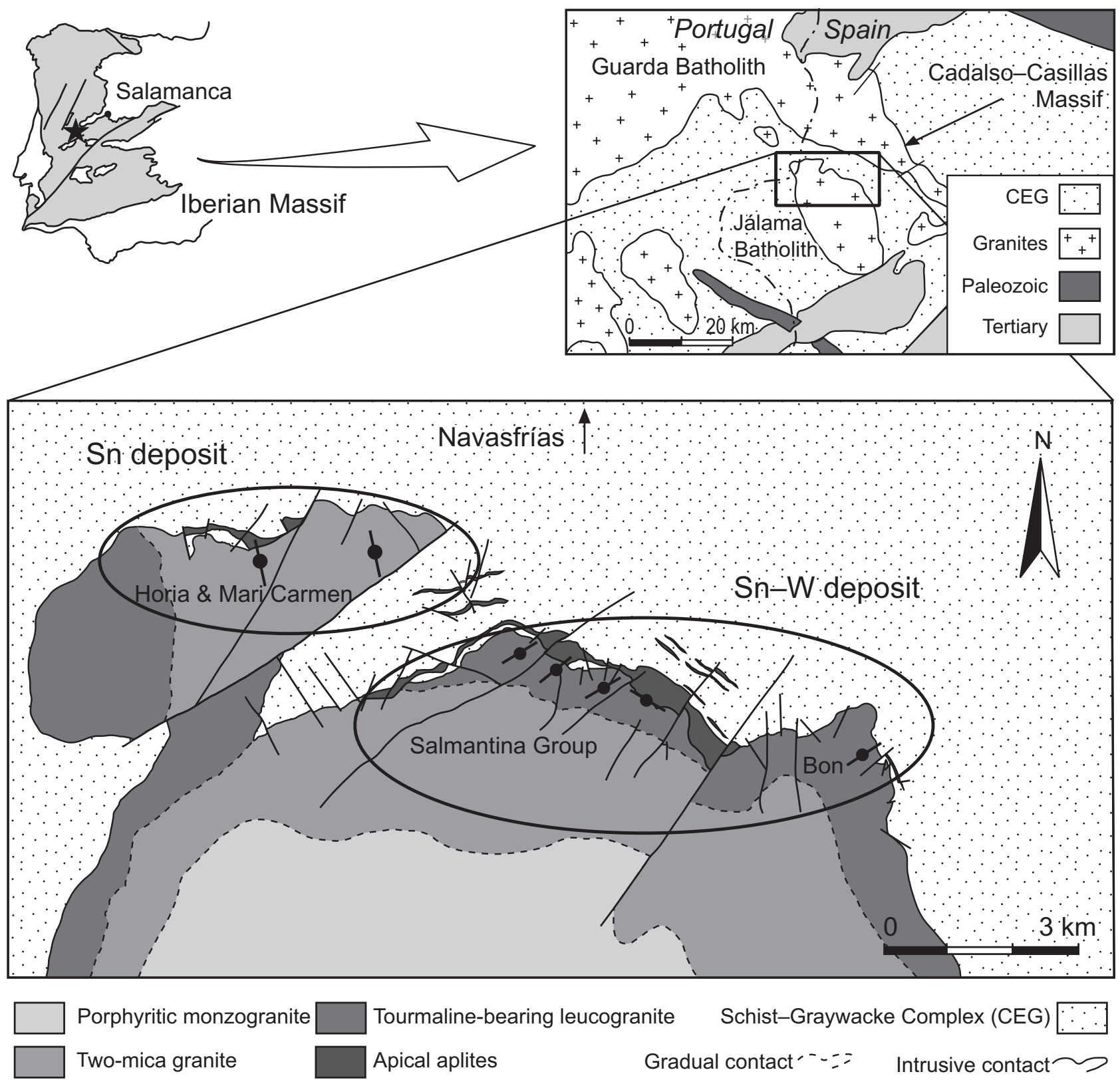

Porphyritic monzogranite Two-mica granite
Tourmaline-bearing leucogranite

Apical aplites

Schist-Graywacke Complex (CEG)

Gradual contact - =: Intrusive contact $\sim$

Fractures $\_$Qtz veins directions

External Unit

Fig. 1 Location of the Jálama Batholith in the Navasfrías Sn-W district (central part of the Iberian Massif). The principal directions of the mineralized quartz veins that were mined can be seen. Based on Ramírez (1996). 
40.265708, -6.79616), in both peri-batholithic pegmatite dikes and in intra-granitic quartz veins. The latter are much more abundant in the tourmaline-bearing leucogranite and the apical aplites than in the two-mica equigranular granite (Fig. 1). Two groups of quartz veins can be distinguished within the Jálama Batholith, depending on the host rock.

(1) Sn-bearing quartz veins are hosted by the twomica equigranular granite of the Horia and Mari Carmen mines. These subvertical veins of tabular or lenticular shape are up to several decimeters thick (Fig. 2a) and are striking mainly $\mathrm{N} 170^{\circ} \mathrm{E}-\mathrm{N} 180^{\circ} \mathrm{E}$. In some cases, the intrusion of these mineralized quartz veins induced a selvage zone $c .2 \mathrm{~cm}$ thick composed of quartz and muscovite along the contact with the granitic host rock (Fig. 2a). The ore minerals generally crystallized both in the centers of the quartz veins, where they are normally related to fractures, and in the outermost zones, forming massive and fine-grained crystalline aggregates.

(2) $\mathrm{Sn}-\mathrm{W}$ mineralization of the Salmantina Group and Bon mines occurs in swarms of quartz veins hosted by the tourmaline-bearing leucogranite and border aplites. These subvertical veins strike predominantly from $\mathrm{N} 70^{\circ} \mathrm{E}$ to $\mathrm{N} 110^{\circ} \mathrm{E}$, which matches most of the old mining works (Fig. 1), as well as constitutes the main lateVariscan fracture system. The subvertical veins striking $\mathrm{N} 40^{\circ} \mathrm{E}$ and $\mathrm{N} 60^{\circ} \mathrm{E}$ are less common. In general, all these quartz veins display mainly lenticular shapes and vary from several centimeters to decimeters in thickness (Fig. 2b). In some cases they are arranged en echelon, indicating that they were formed as a consequence of extensional movements or fractures (Bons 2000). Thus, the direction of these quartz veins changes continuously, leading in places to a development of structures such as stockworks. In these cases, the veins are usually less than $10 \mathrm{~cm}$ thick.

The mineralized quartz veins contain the most important amounts of cassiterite and wolframite, with more than $600 \mathrm{ppm}$ Sn and $1000 \mathrm{ppm} \mathrm{W}$ on average. Additionally, sulphides, such as arsenopyrite and sphalerite, are abundant, together with variable and accessory amounts of pyrite, pyrrhotite, chalcopyrite, stannite, $\mathrm{Bi}-\mathrm{Pb}-\mathrm{Ag}$ sulphosalts, and gold (Moro et al. 2001). Finally, the quartz veins striking preferentially from $\mathrm{N} 90^{\circ} \mathrm{E}$ to $100^{\circ} \mathrm{E}$ contain an interesting phosphate assemblage. This consists mainly of triplite and its alteration products, such as isokite, bermanite, phosphosiderite and fluorapatite (Moro and Llorens 2008; Llorens and Moro 2012a).

\section{Analytical techniques}

A total of 125 samples of the mineralized intra-granitic quartz veins were collected in situ from several zones of the Navasfrías district (Fig. 1). Forty of them
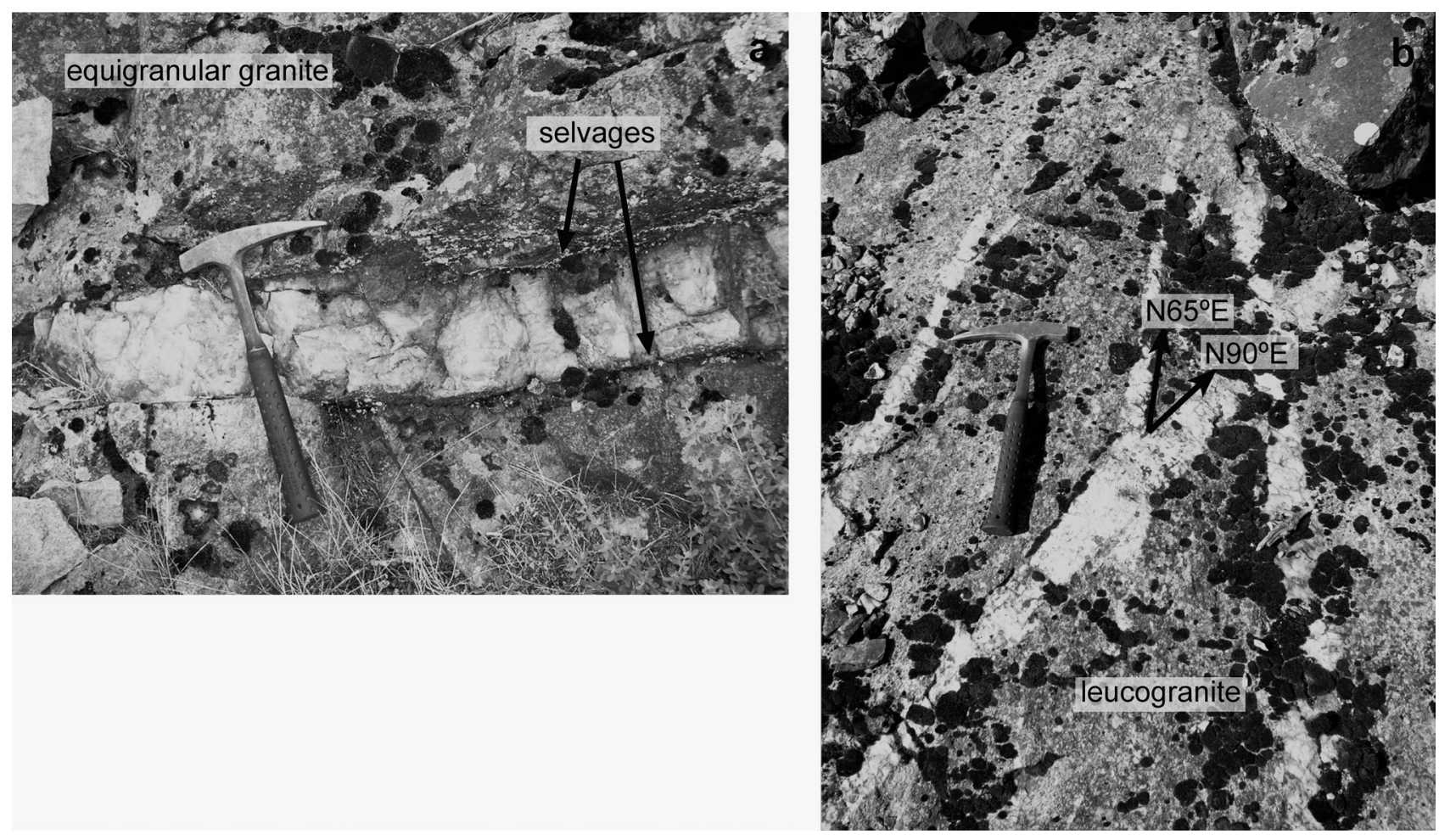

Fig. 2a - Outcrop of the mineralized quartz veins hosted by the two-mica equigranular granite. They strike N180 ${ }^{\circ} \mathrm{E}$ with subvertical dip and have muscovite-rich selvages; $\mathbf{b}-$ Crossing of $\mathrm{N} 0^{\circ} \mathrm{E}$ and $\mathrm{N} 65^{\circ} \mathrm{E}$ striking veins, hosted by the tourmaline-bearing leucogranite of Salmantina Group. 


\begin{tabular}{|l|l|l|l|}
\hline & $\begin{array}{c}\text { Early Sn-W ore } \\
\text { ductile deformation }\end{array}$ & Late deposit \\
\hline Cassiterite & Wolframite \\
Rutile & \\
Ixiolite \\
Fe-Zn sulphides \\
Fe-Cu sulphides \\
Bi-Pb-Ag sulphosalts
\end{tabular}

Fig. 3 Schematic mineral sequence of the Sn-W quartz veins hosted by the granitic facies of the Jálama Batholith.

containing Sn, W and Ti minerals were selected for chemical analyses. A total of 33 electron-microprobe analyses (EMPA) of cassiterite, 13 of ferberite, 20 of hübnerite, 10 of ixiolite, 45 of $\mathrm{Nb}$-Ta-rich rutile, and 7 of rutile have been carried out. The minute size of rutile and ixiolite hindered their separation, such that the use of X-ray diffraction techniques was not possible. Accordingly, their identification was carried out by combined light and electron microscopy for the petrographic and mineralogical study, and was also based on their chemical composition. We employed a Cameca SX-100 electron-microprobe at the ScientificTechnical Services of the University of Oviedo, which was operated with an accelerating voltage of $20 \mathrm{kV}$ and a sample current of $20 \mathrm{nA}$. The counting time was $20 \mathrm{~s}$ for $\mathrm{Zr}, \mathrm{W}, \mathrm{Fe}, \mathrm{Ta}$ and $\mathrm{Al}$, and $10 \mathrm{~s}$ for the rest of elements. The detection limits and standard deviations range between 0.01 and 0.04 wt. \%, and between \pm 0.02 to \pm 0.10 respectively for major and up to $0.11 \mathrm{wt}$. \% and between \pm 0.12 to \pm 0.34 respectively for trace elements. The following standards were used: metals for $\mathrm{Ti}, \mathrm{Sn}, \mathrm{W}$ and $\mathrm{Zr}$, vanadinite for $\mathrm{V}$, magnetite for $\mathrm{Fe}$, $\mathrm{MnTiO}_{3}$ for $\mathrm{Mn}, \mathrm{Ta}_{2} \mathrm{O}_{5}$ for $\mathrm{Ta}, \mathrm{Nb}_{2} \mathrm{O}_{5}$ for $\mathrm{Nb}$, andradite for $\mathrm{Ca}$ and corundum for Al. Back-scattered electron images and semi-quantitative analyses were obtained using the electron-microprobe at the Scientific-Technical Services of the University of Oviedo and the SEM at the University of Salamanca (ZEISS DSM 940) to determine the compositional variations and zoning of the Sn, W and Ti minerals.

\section{Mineralogy and chemistry of the Sn, W and Ti phases}

The formation of the mineralized quartz veins of the Jálama Batholith resulted from a complex polyphase process that involved the injection of different fluids into the same structure (Fig. 3) (Llorens 2011).
At the first step, an early $\mathrm{Sn}-\mathrm{W}$ deposit developed with subordinate rutile and sulphides. After a ductile deformation, the main ore was deposited. An intense fracturing divided this step into two subphases. The first was represented by the crystallization mainly of $\mathrm{Fe}-\mathrm{Zn}$ sulphides and less $\mathrm{Sn}-\mathrm{W}$ minerals. During the second one, abundant $\mathrm{Fe}-\mathrm{Cu}$ sulphides and $\mathrm{Bi}-\mathrm{Pb}-\mathrm{Ag}$ sulphosalts crystallized, together with accessory ixiolite and a second generation of rutile. The final step consisted of a late filling, mainly composed of quartz and, locally, carbonates.

Among the different $\mathrm{Sn}-\mathrm{W}-\mathrm{Nb}-\mathrm{Ta}-\mathrm{Ti}$ deposits of the Navasfrías district, the most important minerals mined in the northern part of the Jálama Batholith were cassiterite and wolframite hosted by the intra-granitic quartz veins of the Horia, Mari Carmen, Salmantina Group and Bon mines. Although subordinately, Ta- and $\mathrm{Nb}$-rich rutile and ixiolite were identified exclusively in the quartz veins of the Salmantina Group.

\subsection{Cassiterite}

Cassiterite is the main ore mineral occurring in the quartz veins of the Jálama Batholith, both in their core parts and, less commonly, in the selvage zones. Cassiterite appears as micrometer- to centimeter-sized (up to $2 \mathrm{~cm}$ long) subhedral to euhedral crystals, as well as anhedral aggregates of more than $5 \mathrm{~cm}$ across. In both cases, simple and polysynthetic twins are more common than elbow twins. Under the optical microscope, the crystals of cassiterite usually show a distinct zoning owing to the alternation of intensely red and paler bands. However, this optical zoning does not respond to any particular chemical variation pattern. Considering the paragenetic relationships, two episodes of cassiterite deposition were identified (Fig. 3): cassiterite I, which is related to the early $\mathrm{Sn}-\mathrm{W}$ precipitation (Fig. 4a), and cassiterite II, which crystallized at the beginning of the main $\mathrm{Fe}-\mathrm{Zn}$ sulphides deposition (Fig. 4b). Rounded 
rutile I crystals, up to $15 \mu \mathrm{m}$, are commonly included in cassiterite II.

There are no chemical differences between the two cassiterite generations. They show a composition close to the ideal $\left(\mathrm{SnO}_{2}\right)$, in which the cationic site is occupied by Sn (0.977-0.993 apfu) and significant contents of Ti (up to 0.012 apfu $\mathrm{TiO}_{2}$ ) (Tab. 1). The Ti contents are significantly higher than those found in the cassiterite hosted by pegmatite dikes of the Jálama Batholith (Llorens and Moro 2012b). Moreover, $\mathrm{Fe}, \mathrm{Nb}$ and $\mathrm{W}$ may be present in the crystal structure of cassiterite as trace elements. Tungsten is generally related to the presence of wolframite in the quartz veins hosted by the tourmaline-bearing leucogranite and apical aplites.

\subsection{Wolframite}

Wolframite occurs exclusively in swarms of quartz veins striking from $\mathrm{N} 70^{\circ} \mathrm{E}$ to $\mathrm{N} 110^{\circ} \mathrm{E}$, which are hosted by the tourmaline-bearing leucogranite and the border aplites. It crystallized especially within the outermost zones of the veins, and may be associated with cassiterite crystals. Wolframite appears as single prismatic crystals forming millimeter-to-centimeter sized crystalline aggregates perpendicular to the walls of the quartz veins (Fig. 4c). As in the case of cassiterite, two episodes of wolframite growth were identified based on the textural and compositional features. Wolframite I crystallized during the early stages of mineralization together with cassiterite I. Its composition is predominantly ferberitic, being locally enriched in $\mathrm{Mn}$ in some veins. Wolframite II was formed during the first episode of the main ore deposition, associated with cassiterite II, and is dominated by a hübneritic component. In many cases, crystals of wolframite I (ferberite) were partially dissolved and recrystallized later as wolframite II (hübnerite) (Fig. 4d).

The average ferberite composition corresponds to the formula $\left(\mathrm{Fe}_{0.61} \mathrm{Mn}_{0.36}\right)_{\Sigma 0.97} \mathrm{WO}_{4}$, where $\mathrm{W}$ has been substituted by up to 0.024 apfu $\mathrm{Zr}$ and traces of $\mathrm{Nb}$ (up to 0.011 apfu) (Tab. 2). The contents of $\mathrm{Fe}^{3+}$, calculated by charge balance for two cations (Ercit et al. 1992), are always less than $0.020 \mathrm{apfu}$. A strong enrichment in $\mathrm{Fe}$ is notewor-
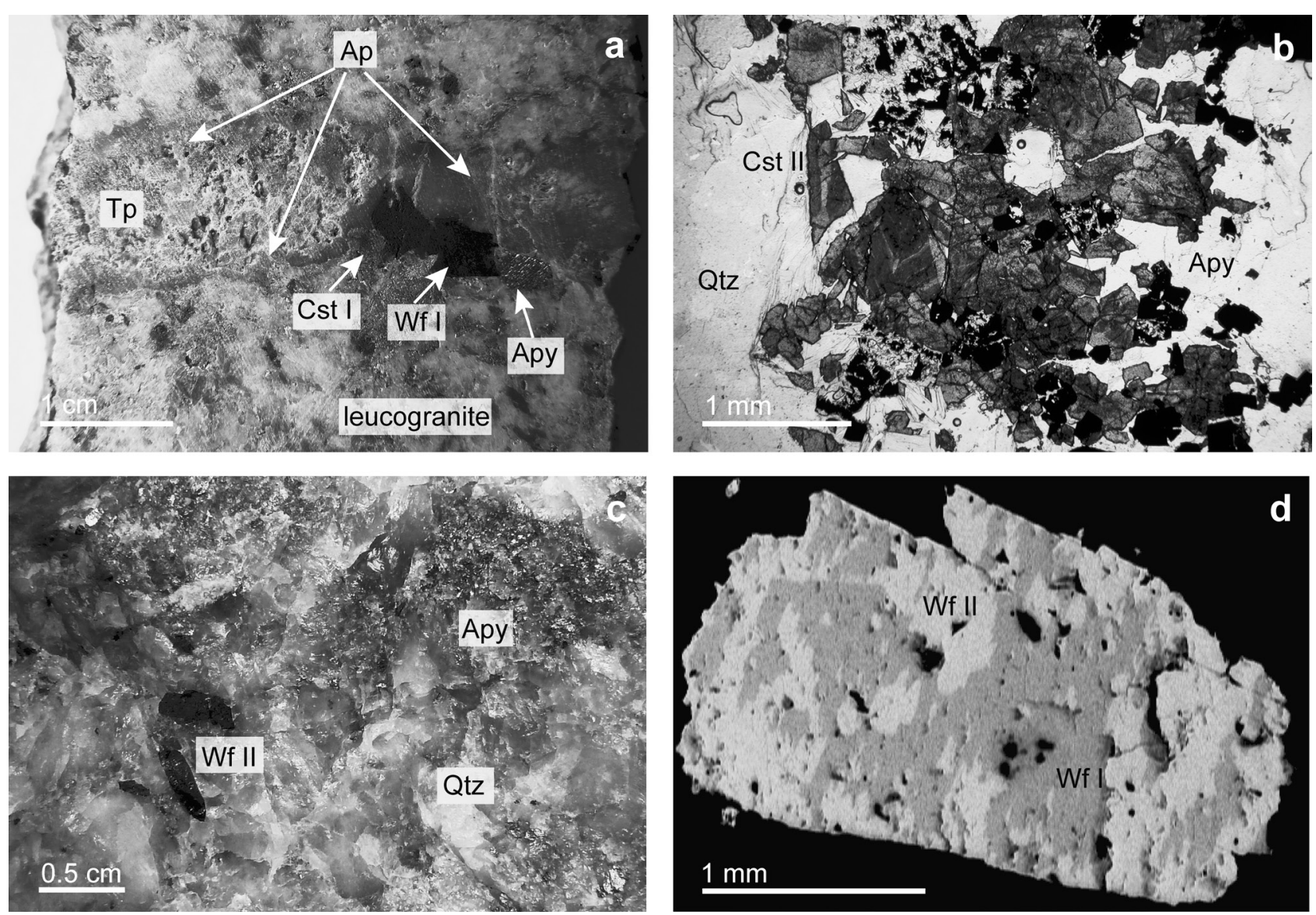

Fig. 4a - Fragment of a mineralized quartz vein of the Salmantina Group with cassiterite I (Cst I), wolframite I (Wf I) and arsenopyrite (Apy), together with triplite (Tp) and apatite (Ap); b - Microscopic image of zoned cassiterite II (Cst II) aggregates with arsenopyrite (plain transmitted light); $\mathbf{c}$ - Subhedral crystals of wolframite II (Wf II) and arsenopyrite aggregates in a quartz vein (Qtz); d - BSE image of wolframite I with a patchy zoning as a consequence of replacement by wolframite II. 
Tab. 1 Representative compositions of cassiterite (wt. \% and apfu)

\begin{tabular}{|c|c|c|c|c|}
\hline \multirow{2}{*}{$\begin{array}{l}\text { Vein host } \\
\text { Sample }\end{array}$} & \multicolumn{2}{|c|}{ Equigranular granite } & \multicolumn{2}{|c|}{ Leucogranite/aplites } \\
\hline & 1711 & $1775 \mathrm{~B}$ & 1691 & 1785B \\
\hline Analysis & 3.3 & 1.7 & 6.5 & 2.1 \\
\hline $\mathrm{WO}_{3}$ & 0.00 & 0.00 & 0.07 & 0.04 \\
\hline $\mathrm{Nb}_{2} \mathrm{O}_{5}$ & 0.17 & 0.00 & 0.24 & 0.42 \\
\hline $\mathrm{Ta}_{2} \mathrm{O}_{5}$ & 0.00 & 0.00 & 0.00 & 0.00 \\
\hline $\mathrm{TiO}_{2}$ & 0.48 & 0.73 & 0.60 & 0.03 \\
\hline $\mathrm{ZrO}_{2}$ & 0.00 & 0.00 & 0.00 & 0.00 \\
\hline $\mathrm{SnO}_{2}$ & 98.57 & 99.00 & 98.83 & 99.05 \\
\hline $\mathrm{Al}_{2} \mathrm{O}_{3}$ & 0.00 & 0.00 & 0.00 & 0.00 \\
\hline $\mathrm{V}_{2} \mathrm{O}_{3}$ & b.d.1. & b.d.l. & 0.00 & b.d.1. \\
\hline $\mathrm{MnO}$ & 0.04 & 0.02 & 0.00 & 0.00 \\
\hline $\mathrm{FeO}$ & 0.07 & 0.00 & 0.09 & 0.18 \\
\hline Total & 99.35 & 99.79 & 99.83 & 99.72 \\
\hline W & 0.000 & 0.000 & 0.000 & 0.000 \\
\hline $\mathrm{Nb}$ & 0.002 & 0.000 & 0.002 & 0.004 \\
\hline $\mathrm{Ta}$ & 0.000 & 0.000 & 0.000 & 0.000 \\
\hline $\mathrm{Ti}$ & 0.008 & 0.012 & 0.010 & 0.001 \\
\hline $\mathrm{Zr}$ & 0.000 & 0.000 & 0.000 & 0.000 \\
\hline $\mathrm{Sn}$ & 0.988 & 0.987 & 0.985 & 0.992 \\
\hline $\mathrm{Al}$ & 0.000 & 0.000 & 0.000 & 0.000 \\
\hline V & 0.000 & 0.000 & 0.000 & 0.000 \\
\hline $\mathrm{Mn}$ & 0.001 & 0.000 & 0.000 & 0.000 \\
\hline $\mathrm{Fe}$ & 0.001 & 0.000 & 0.002 & 0.003 \\
\hline$\sum$ cat. & 1000 & 1000 & 1000 & 1000 \\
\hline $\mathrm{Mn} /(\mathrm{Mn}+\mathrm{Fe})$ & 0.375 & 0.943 & 0.011 & 0.000 \\
\hline $\mathrm{Ta} /(\mathrm{Ta}+\mathrm{Nb})$ & 0.000 & 0.000 & 0.000 & 0.000 \\
\hline
\end{tabular}

$\mathrm{N}^{\circ}$ of ions (in apfu) calculated on the basis of $2 \mathrm{O}$; b.d.1.: below detection limit.

thy in the wolframite I crystallized in one of the mines located in the apical parts of the Jálama granitic cupola (Bon mine, Fig. 1). As mentioned above, only wolframite I crystallized in a sample of the quartz veins (Salmantina Group mine), shows a hübneritic composition despite belonging to the same mineralization event. The mean formula of this hübnerite $\mathrm{I}$ is $\left(\mathrm{Fe}_{0.41} \mathrm{Mn}_{0.58}\right)_{\Sigma 1} \mathrm{WO}_{4}$, whereby $\mathrm{Nb}$ substitutes for up to 0.011 apfu of W. In contrast, several crystals of wolframite II (hübnerite) contain higher amounts of $\mathrm{Fe}^{3+}$ than the earlier ferberite (up to 0.090 apfu), with an average formula $\left(\mathrm{Fe}_{0.37} \mathrm{Mn}_{0.61}\right)_{\Sigma 0.98} \mathrm{WO}_{4}$ (Tab. 2).

\subsection{Ixiolite}

Ixiolite was only identified in the quartz veins hosted by the tourmaline-bearing leucogranite and the border aplites of the Salmantina Group. It occurs as acicular crystals or anhedral aggregates that fill holes and fractures, together with rutile II, preferentially associated with sulphides (Fig. 5a-b). According to the textural features, ixiolite crystallized slightly earlier than rutile II, as the latter mineral coated several crystals of the former (Fig. 5a). Ixiolite commonly shows a zoned tex-
Tab. 2 Representative compositions of wolframite (wt. \% and apfu)

\begin{tabular}{|c|c|c|c|c|c|c|}
\hline Vein host & & & eucogra & ites/aplit & & \\
\hline Mineral & Wf I & Wf I & Wf I & Wf II & Wf II & Wf II \\
\hline Analysis & 1.1 & 2.2 & 5.2 & 1.1 & 2.3 & 6.2 \\
\hline $\mathrm{WO}_{3}$ & 75.78 & 75.53 & 74.90 & 76.36 & 74.60 & 76.14 \\
\hline $\mathrm{Nb}_{2} \mathrm{O}_{5}$ & 0.17 & 0.33 & 0.33 & 0.26 & 0.47 & 0.25 \\
\hline $\mathrm{Ta}_{2} \mathrm{O}_{5}$ & 0.00 & 0.07 & 0.00 & 0.00 & b.d.l. & 0.00 \\
\hline $\mathrm{TiO}_{2}$ & 0.06 & b.d.1. & b.d.l. & 0.02 & 0.08 & 0.03 \\
\hline $\mathrm{ZrO}_{2}$ & 0.82 & 0.90 & 0.89 & 0.70 & 0.73 & 0.86 \\
\hline $\mathrm{SnO}_{2}$ & 0.00 & 0.02 & 0.03 & b.d.1. & 0.06 & 0.00 \\
\hline $\mathrm{Al}_{2} \mathrm{O}_{3}$ & 0.00 & 0.00 & 0.00 & 0.00 & 0.00 & 0.00 \\
\hline $\mathrm{V}_{2} \mathrm{O}_{3}$ & 0.00 & 0.00 & 0.00 & b.d.l. & 0.00 & 0.00 \\
\hline $\mathrm{CaO}$ & b.d.l. & b.d.l. & 0.03 & b.d.l. & 0.02 & 0.02 \\
\hline $\mathrm{MnO}$ & 9.71 & 13.38 & 1.98 & 14.29 & 13.41 & 16.09 \\
\hline $\mathrm{FeO}$ & 13.42 & 9.98 & 21.50 & 9.08 & 10.11 & 6.78 \\
\hline Total & 99.95 & 100.23 & 99.67 & 100.75 & 99.49 & 100.16 \\
\hline W & 0.992 & 0.981 & 0.978 & 0.990 & 0.971 & 0.996 \\
\hline $\mathrm{Nb}$ & 0.004 & 0.008 & 0.008 & 0.006 & 0.011 & 0.006 \\
\hline $\mathrm{Ta}$ & 0.000 & 0.001 & 0.000 & 0.000 & 0.000 & 0.000 \\
\hline $\mathrm{Ti}$ & 0.001 & 0.0004 & 0.000 & 0.001 & 0.003 & 0.001 \\
\hline $\mathrm{Zr}$ & 0.020 & 0.022 & 0.022 & 0.017 & 0.018 & 0.021 \\
\hline $\mathrm{Sn}$ & 0.000 & 0.001 & 0.001 & 0.000 & 0.001 & 0.000 \\
\hline $\mathrm{Al}$ & 0.000 & 0.000 & 0.000 & 0.000 & 0.000 & 0.000 \\
\hline V & 0.000 & 0.000 & 0.000 & 0.001 & 0.000 & 0.000 \\
\hline $\mathrm{Ca}$ & 0.001 & 0.001 & 0.002 & 0.001 & 0.001 & 0.001 \\
\hline Mn & 0.415 & 0.568 & 0.085 & 0.605 & 0.570 & 0.688 \\
\hline $\mathrm{Fe}^{2+}$ & 0.567 & 0.418 & 0.880 & 0.380 & 0.380 & 0.286 \\
\hline $\mathrm{Fe}^{3+*}$ & 0.000 & 0.000 & 0.020 & 0.000 & 0.040 & 0.000 \\
\hline$\sum$ cat. & 2000 & 2000 & 1994 & 2000 & 1995 & 2000 \\
\hline $\mathrm{Mn} /(\mathrm{Mn}+\mathrm{Fe})$ & 0.423 & 0.576 & 0.086 & 0.615 & 0.573 & 0.706 \\
\hline $\mathrm{Ta} /(\mathrm{Ta}+\mathrm{Nb})$ & 0.016 & 0.106 & 0.000 & 0.000 & 0.010 & 0.000 \\
\hline
\end{tabular}

$\mathrm{N}^{\circ}$ of ions (in apfu) calculated on the basis of $4 \mathrm{O}$; b.d.1.: below detection limit.

* Calculated by charge balance (Ercit et al. 1992).

ture owing to slight variations in its $\mathrm{Nb}, \mathrm{Ta}, \mathrm{Ti}$ and $\mathrm{W}$ contents (Fig. 5b). It has a rutile-type general formula ( $\mathrm{Ta}, \mathrm{Nb}, \mathrm{Sn}, \mathrm{Fe}, \mathrm{Mn}) \mathrm{O}_{2}$ containing high $\mathrm{Nb}$ (between 0.240 and $0.450 \mathrm{apfu}$ ), Ta (between 0.073 and $0.357 \mathrm{apfu}$ ), W (up to $0.111 a p f u$ ) and $\mathrm{Ti}$ (up to $0.139 a p f u$ ), and only traces of Sn (up to 0.02 apfu). A significant enrichment in $\mathrm{Fe}$ (up to 0.272 apfu) and minor in Mn (up to 0.130 apfu) was noted (Tab. 3).

\subsection{Rutile}

Two types of rutile were identified texturally and chemically in the mineralized quartz veins. Rutile I crystallized preferentially in the quartz veins hosted by the two-mica equigranular granite of the Horia and Mari Carmen mines (Fig. 1). It occurs as micrometer-sized anhedral crystals, included in the colorless zones of cassiterite I. Its chemical composition is dominated by $\mathrm{Ti}$, which occupies most of the cationic site, varying from 0.890 to 0.946 apfu. Titanium is partially substituted 

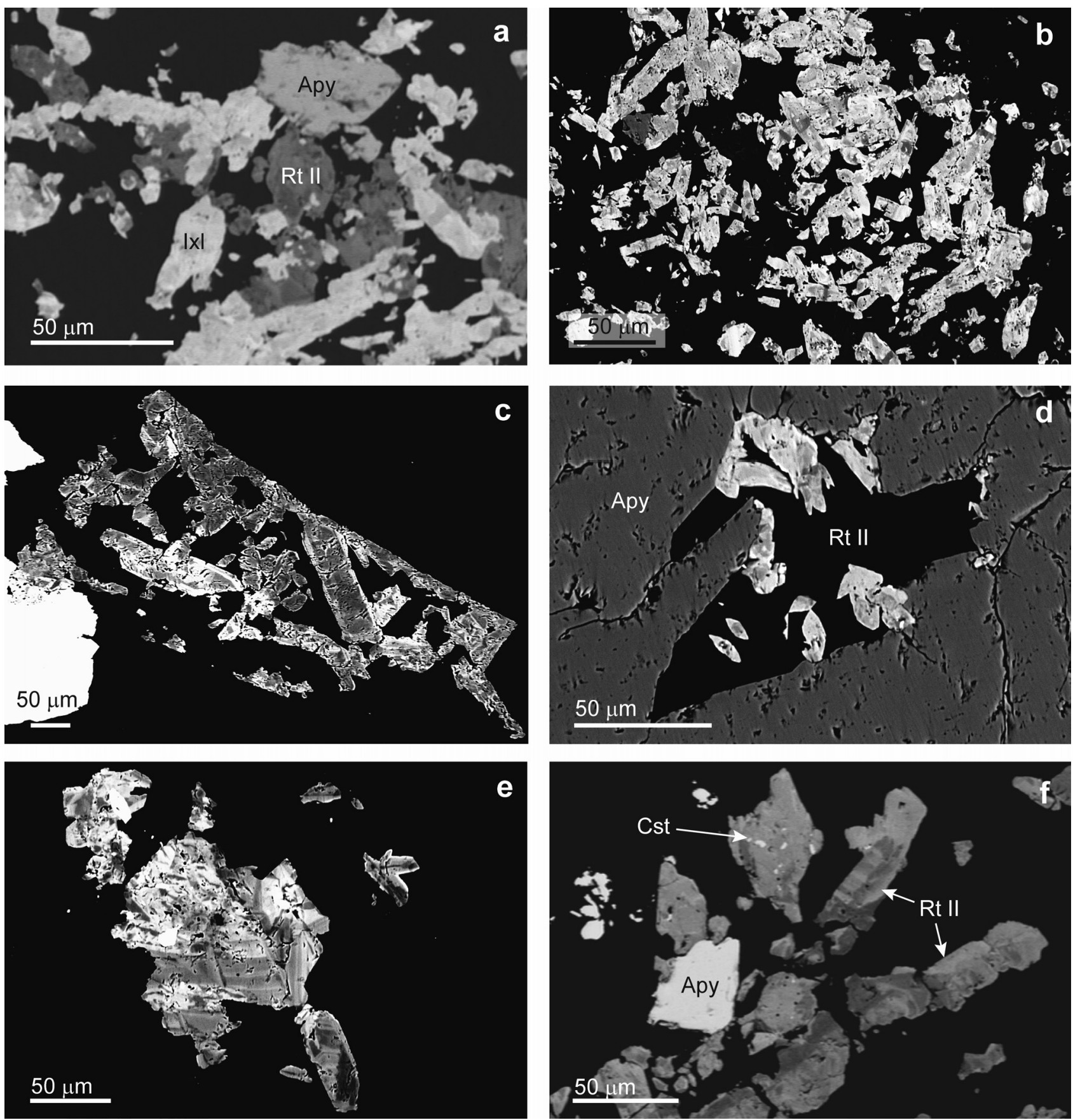

Fig. 5 BSE images of the late $\mathrm{Nb}$, Ta, Ti and $\mathrm{W}$ oxides of the mineralized quartz veins: a - Rutile II (Rt II) aggregates surrounding ixiolite (Ixl) crystals; $\mathbf{b}$ - Oscillatory zoning of the subhedral to euhedral crystals of ixiolite reflecting variations in the Nb, Ta, Ti and W contents; $\mathbf{c}-\mathrm{Aggre}-$ gates of zoned euhedral crystals of rutile II with higher Ti contents in the inner zones (dark grey) and higher Ta contents towards the rims (light grey); d - Aggregates of rutile II filling cavities in arsenopyrite (Apy); e - Aggregates of rutile II crystals hosted by quartz, showing oscillatory zoning in the outermost zones and patchy zoning in the inner ones, the latter as a consequence of the presence of exsolution lamellae containing variable amounts of $\mathrm{Nb}$ and Ta; $\mathbf{f}$ - Rutile II crystals with partially dissolved rims which have been recrystallized incorporating high Ta contents and containing cassiterite inclusions (Cst).

by variable amounts of $\mathrm{Nb}, \mathrm{Ta}, \mathrm{Fe}$ and $\mathrm{Sn}$, although $\mathrm{Sn}$ contents are in some cases increased as a consequence of contamination from the host cassiterite. As occurs in various intra-granitic pegmatite dikes of the Jálama Batholith, several rutile I crystals of the quartz veins contain high quantities of $\mathrm{Al}_{2} \mathrm{O}_{3}$, reaching 1.33 wt. $\%$ (Tab. 3).

Rutile II crystallized in the quartz veins hosted by the tourmaline-bearing leucogranite and the border aplites of the Salmantina Group as micrometer-to- 
Tab. 3 Representative compositions of ixiolite and rutile (wt. \% and apfu)

\begin{tabular}{|c|c|c|c|c|c|c|c|c|c|c|c|}
\hline \multirow{2}{*}{$\begin{array}{l}\text { Vein host } \\
\text { Mineral }\end{array}$} & \multicolumn{9}{|c|}{ Leucogranite/aplites } & \multicolumn{2}{|c|}{ Equigranular grt. } \\
\hline & Ixl & Ixl & Ixl & Ixl & Rt II & Rt II & Rt II & Rt II & Rt II & Rt I & Rt I \\
\hline Analysis & 3.2 & 5.1 & 5.3 & 5.4 & 1.B.6 & 1.B.7 & 2.1 & $3.3 \mathrm{a}$ & 4.3 & 1.7 & 1.2 \\
\hline $\mathrm{WO}_{3}$ & 9.82 & 16.99 & 4.20 & 17.00 & 6.79 & 0.50 & 0.11 & - & 1.27 & 0.20 & 0.23 \\
\hline $\mathrm{Nb}_{2} \mathrm{O}_{5}$ & 38.30 & 40.41 & 22.07 & 31.28 & 7.48 & 14.27 & 8.04 & 7.28 & 1.37 & 6.10 & 1.60 \\
\hline $\mathrm{Ta}_{2} \mathrm{O}_{5}$ & 22.82 & 20.03 & 54.68 & 31.23 & 2.47 & 8.61 & 21.65 & 11.12 & 1.24 & 3.58 & 1.22 \\
\hline $\mathrm{TiO}_{2}$ & 8.82 & 2.67 & 2.96 & 2.81 & 75.48 & 68.44 & 62.35 & 74.43 & 91.53 & 84.11 & 89.63 \\
\hline $\mathrm{SnO}_{2}$ & 0.99 & 0.67 & 0.75 & 0.68 & 0.93 & 1.17 & 0.78 & 0.33 & 0.73 & 2.25 & 1.97 \\
\hline $\mathrm{Al}_{2} \mathrm{O}_{3}$ & b.d.1. & 0.21 & b.d.1. & 0.00 & 0.91 & b.d.l. & b.d.1. & 3.34 & b.d.1. & 0.11 & 1.33 \\
\hline $\mathrm{V}_{2} \mathrm{O}_{3}$ & b.d.l. & - & - & - & - & - & - & - & - & 0.69 & 0.44 \\
\hline $\mathrm{CaO}$ & b.d.1. & b.d.1. & 0.00 & 0.00 & 0.00 & 0.028 & 0.00 & b.d.1. & 0.00 & b.d.1. & 0.13 \\
\hline $\mathrm{MnO}$ & 4.25 & 6.20 & 3.25 & 3.61 & 0.00 & 0.03 & 0.02 & 0.00 & 0.00 & 0.05 & b.d.l. \\
\hline $\mathrm{FeO}$ & 12.98 & 12.45 & 11.76 & 13.17 & 4.34 & 5.48 & 5.60 & 2.30 & 2.08 & 3.12 & 1.75 \\
\hline $\mathrm{W}$ & 0.053 & 0.095 & 0.026 & 0.099 & 0.026 & 0.002 & 0.000 & - & 0.005 & 0.001 & 0.001 \\
\hline $\mathrm{Nb}$ & 0.364 & 0.393 & 0.240 & 0.319 & 0.050 & 0.098 & 0.059 & 0.050 & 0.009 & 0.039 & 0.010 \\
\hline $\mathrm{Ta}$ & 0.130 & 0.117 & 0.358 & 0.191 & 0.010 & 0.036 & 0.095 & 0.046 & 0.005 & 0.014 & 0.005 \\
\hline $\mathrm{Ti}$ & 0.139 & 0.043 & 0.054 & 0.048 & 0.842 & 0.782 & 0.758 & 0.843 & 0.954 & 0.891 & 0.946 \\
\hline $\mathrm{Zr}$ & 0.000 & 0.002 & 0.000 & 0.001 & 0.012 & 0.010 & 0.009 & 0.011 & 0.012 & 0.000 & 0.001 \\
\hline $\mathrm{Sn}$ & 0.009 & 0.006 & 0.008 & 0.007 & 0.006 & 0.008 & 0.006 & 0.002 & 0.004 & 0.014 & 0.012 \\
\hline Al & 0.000 & 0.005 & 0.000 & 0.000 & 0.016 & 0.001 & 0.001 & 0.059 & 0.001 & 0.002 & 0.022 \\
\hline V & 0.000 & - & - & - & - & - & - & - & - & 0.006 & 0.004 \\
\hline $\mathrm{Ca}$ & 0.001 & 0.001 & 0.000 & 0.000 & 0.000 & 0.000 & 0.000 & 0.001 & 0.000 & 0.001 & 0.002 \\
\hline $\mathrm{Mn}$ & 0.076 & 0.113 & 0.066 & 0.069 & 0.000 & 0.000 & 0.000 & 0.000 & 0.000 & 0.001 & 0.000 \\
\hline $\mathrm{Fe}$ & 0.228 & 0.224 & 0.237 & 0.248 & 0.054 & 0.070 & 0.076 & 0.029 & 0.024 & 0.037 & 0.020 \\
\hline$\sum$ cat. & 1006 & 0.999 & 0.991 & 0.981 & 1011 & 1008 & 1004 & 1040 & 1013 & 1006 & 1023 \\
\hline $\mathrm{Mn} /(\mathrm{Mn}+\mathrm{Fe})$ & 0.249 & 0.335 & 0.219 & 0.217 & 0.000 & 0.005 & 0.004 & 0.000 & 0.000 & 0.015 & 0.004 \\
\hline
\end{tabular}

$\mathrm{N}^{\circ}$ of ions (in apfu) calculated on the basis of $2 \mathrm{O}$.

Ixl: ixiolite; Rt: rutile. b.d.1.: below detection limit. -: not detected.

millimeter subhedral to euhedral crystals (Fig. 5c). In some cases, rutile II with ixiolite filled interstitial spaces, forming anhedral aggregates of small euhedral to subhedral grains (Fig. 5d). According to Carruzzo et al. (2006), such growth might have been caused by the crystallization of rutile II from several randomly oriented nuclei, which eventually would have amalgamated into larger grains if there was no interaction with other crystals that could have stopped their growth. Under the optical microscope, rutile II shows a more or less regular oscillatory zoning, and in some cases a patchy zoning (Fig. $5 \mathrm{c}-\mathrm{e}$ ), generally owing to variations in the Ti content (ranging from 0.675 apfu in the lighter zones to 0.980 apfu in the darker ones). Niobium and tantalum replace $\mathrm{Ti}$ in similar proportions: up to 0.119 apfu each (Tab. 3). The borders of the crystals are generally enriched in $\mathrm{Nb}, \mathrm{W}$ and, especially, in $\mathrm{Ta}$; partial dissolution and recrystallization textures are common (Fig. 5f). The $\mathrm{WO}_{3}$ contents are less than 3.00 wt. \%, whereas $\mathrm{SnO}_{2}$ contents remain more or less invariable in all samples, reaching $2.50 \mathrm{wt}$. \%. Rutile II shows low $\mathrm{Mn}$ and $\mathrm{Fe}^{2+}$ concentrations. Most of rutile II crystals show c. $0.20-0.30$ wt. $\% \mathrm{Al}_{2} \mathrm{O}_{3}$. However, several grains contain higher amounts of $\mathrm{Al}$, reaching 3.34 wt. $\% \mathrm{Al}_{2} \mathrm{O}_{3}$. Relatively high $\mathrm{ZrO}_{2}$ contents are noteworthy in all samples of rutile II, varying from 0.99 to 1.98 wt. \% (Tab. 3 ).

\section{Discussion}

Commonly, a combination of changes in the $P-T-X$ conditions of the granitic host rock with the chemical disequilibrium of fluids are usually invoked to explain the compositional variations responsible, for example, for primary zoning of minerals (Carruzzo et al. 2006). Thus, the stability of cassiterite and the columbite group minerals in highly differentiated rocks would have been induced by different factors controlling variations of the major components of these minerals (e.g., Sn, Nb, Ta, Fe and $\mathrm{Mn}$ ) in the fluid, such as falling temperature, changing oxygen fugacity, activities variations, equilibriumdisequilibrium with the fluid phase, or any combination of the above. However, these elements, together with $\mathrm{W}$ and $\mathrm{Zr}$, represent trace components which would have replaced $\mathrm{Ti}$ in the rutile composition. 


\subsection{Zoning patterns and substitution mechanisms}

\subsubsection{Cassiterite}

Generally, much of $\mathrm{Nb}$, $\mathrm{Ta}$ and $\mathrm{Fe}$ present in cassiterite analyses should be attributed to submicroscopic inclusions and exsolutions, impossible to be detected by EMPA. However, the $(\mathrm{Ta}+\mathrm{Nb}) /(\mathrm{Fe}+\mathrm{Mn})$ ratios in all the cassiterite crystals are less than 2 , indicating that the $\mathrm{Nb}$ content is not exclusively controlled by the inclusions and exsolved blebs of columbite-group minerals (Möller et al. 1988; Neiva 1996).

Thus, the $(\mathrm{Nb}+\mathrm{Ta})$ versus the $(\mathrm{Fe}+\mathrm{Mn})$ plot for cassiterite from the intra-granitic quartz veins (Fig. 6a) shows a roughly 2:1 positive correlation. This suggests a significant role of the ideal $(\mathrm{Fe}, \mathrm{Mn})^{2+}+2(\mathrm{Nb}, \mathrm{Ta})^{5+}$ $\leftrightarrow 3(\mathrm{Sn}, \mathrm{Ti})^{4+}$ substitution to explain the incorporation of $\mathrm{Nb}$ and $\mathrm{Ta}$ in the cassiterite crystal lattice (Černý et al. 1985). The high Ti contents most of the cassiterite crystals of these quartz veins could furthermore indicate a certain influence of the $\mathrm{Sn}^{4+} \leftrightarrow \mathrm{Ti}^{4+}$ isovalent substitution (Spilde and Shearer 1992).

\subsubsection{Wolframite}

Niobium commonly substitutes for $\mathrm{W}$ in many crystals of wolframite, both primary and secondary, as seen in Fig. 6b, where $\mathrm{Nb}$ correlates negatively with $\mathrm{W}$. Although in general the $\mathrm{Nb}$ concentration in wolframite does not seem to depend on the hübneritic component of the crystals, those richer in Mn (wolframite II) incorporate most $\mathrm{Nb}$. The strong negative correlation shown in Fig. $6 \mathrm{c}$ suggests that $\mathrm{Nb}$ entered the wolframite structure in solid solution, probably by means of the $\left[(\mathrm{Fe}, \mathrm{Mn})^{2+}, \mathrm{W}^{6+}\right] \leftrightarrow\left(\mathrm{Fe}^{3+}, \mathrm{Nb}^{5+}\right)$ coupled substitution (Polya 1988; Neiva 2008). This substitution mechanism has been documented in other W-bearing deposits, such as at Panasqueira or Vale das Gatas, Portugal (Neiva 2008). The fact that both cassiterite and wolframite that crystallized in the quartz veins of the Jálama Batholith contain similar $\mathrm{Nb}$ concentrations (up to 0.46 wt. \% $\mathrm{Nb}_{2} \mathrm{O}_{5}$ in cassiterite) suggests that both minerals were formed contemporaneously, as also suggested by textural evidence.

Furthermore, the $\mathrm{Fe}^{3+}$ contents in hübnerite, which crystallized during the main ore-forming episode (Fig. 3), are significantly higher than those observed in earlier ferberite. This suggests a slight increase in $f \mathrm{O}_{2}$, and hence the evolution of the fluids towards more oxidizing conditions, favoring the incorporation of $\mathrm{Nb}$ into wolframite (Tindle and Webb 1989). Hübnerite crystallized during the first subphase of the main mineralization, in which the wolframite II
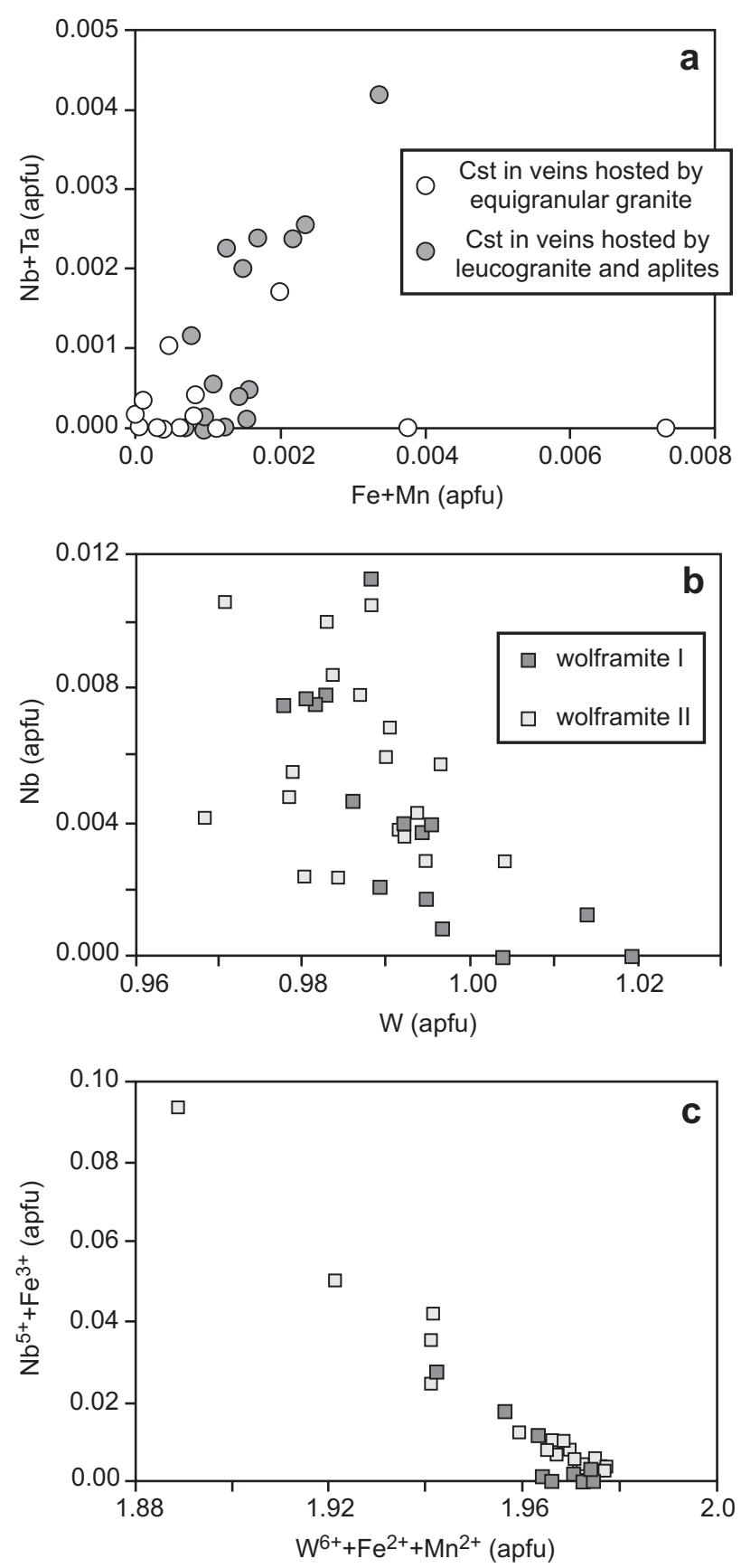

Fig. $6 \mathbf{a}-\mathrm{Nb}+\mathrm{Ta} v s$. $\mathrm{Fe}+\mathrm{Mn}$ diagram of cassiterite from the intragranitic quartz veins. Variation diagrams for wolframite I and II of the quartz veins hosted by the tourmaline-bearing leucogranite and apical aplites: b $-\mathrm{Nb}$ vs. $\mathrm{W} ; \mathbf{c}-\mathrm{Nb}^{5+}+\mathrm{Fe}^{3+}$ vs. $\mathrm{W}^{6+}+\mathrm{Fe}^{2+}+\mathrm{Mn}^{2+}$.

and the cassiterite II were associated with $\mathrm{Fe}-\mathrm{Zn}$ sulphides, the most abundant minerals in the quartz veins at that stage. Accordingly, the enrichment in both $\mathrm{Mn}$ and $\mathrm{Nb}$ in hübnerite seems to have been controlled by decreasing temperatures and the fact that the $\mathrm{Fe}$ of the mineralized fluid was preferentially incorporated into sulphides, such as arsenopyrite, pyrite and sphalerite (Groves and Baker 1972). 

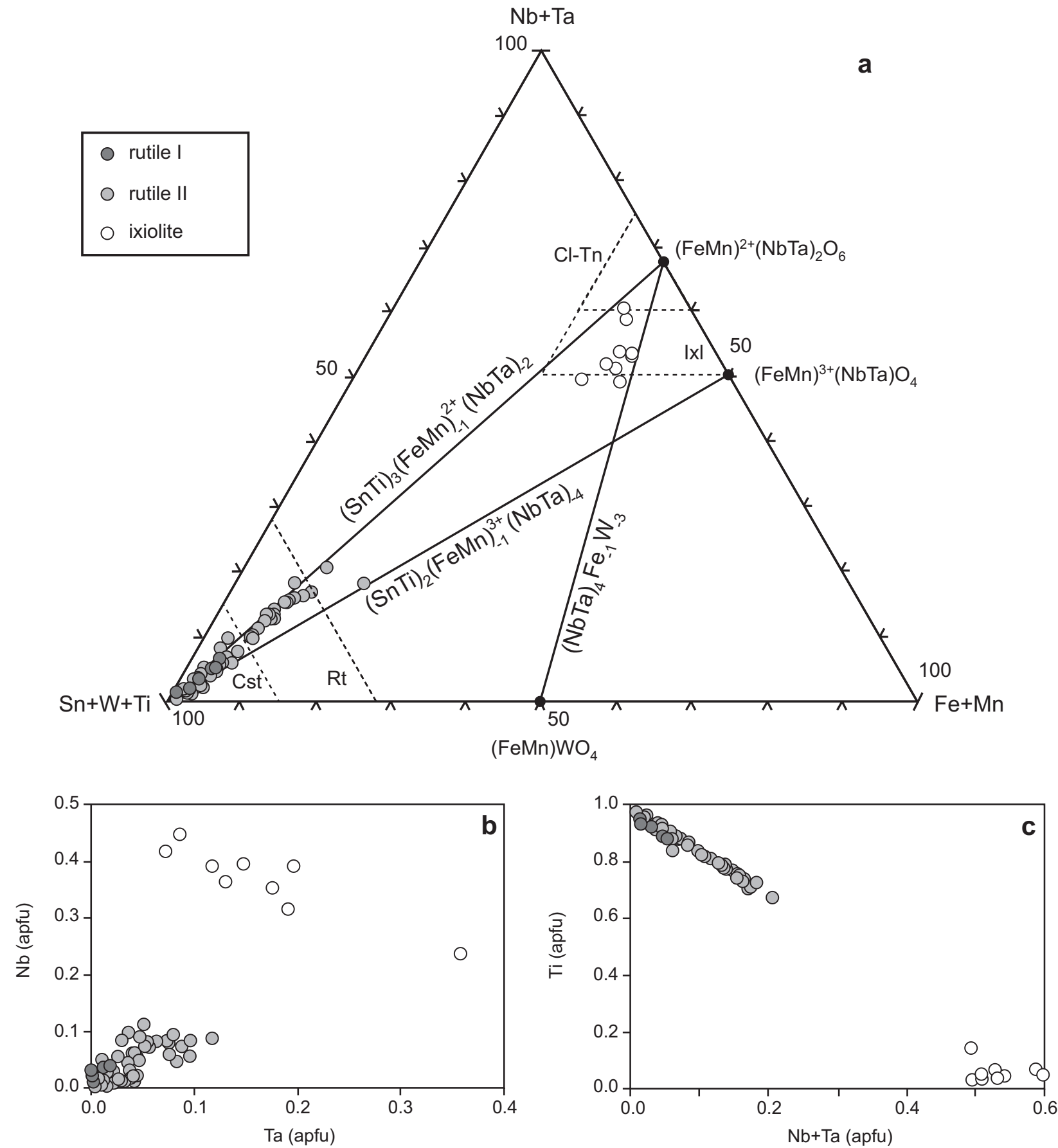

Fig. 7a - Triangular diagram $(\mathrm{Sn}+\mathrm{W}+\mathrm{Ti})-(\mathrm{Nb}+\mathrm{Ta})-(\mathrm{Fe}+\mathrm{Mn})$ for rutile I and II (Rt) and ixiolite (Ixl) in the intra-granitic mineralized quartz veins, showing the dominant substitution mechanism. Variation diagrams for rutile and ixiolite: $\mathbf{b}-\mathrm{Nb}$ vs. Ta; $\mathrm{c}-\mathrm{Ti}$ vs. $\mathrm{Nb}+\mathrm{Ta}$.

\subsubsection{Ixiolite}

In the triangular diagram (Fig. 7a), the ixiolite data are generally observed to be aligned along the (Sn,Ti) $-(\mathrm{Fe}, \mathrm{Mn})^{2+}(\mathrm{Nb}, \mathrm{Ta})_{2}$ join, suggesting the $(\mathrm{Fe}, \mathrm{Mn})^{2+}+$ $2(\mathrm{Nb}, \mathrm{Ta})^{5+} \leftrightarrow 3(\mathrm{Sn}, \mathrm{Ti})^{4+}$ mechanism of substitution for the incorporation of these elements into the ixiolite structure (Černý et al. 1986). However, these compo- sitions deviate slightly from that join in the ( $\mathrm{Sn}, \mathrm{Ti})-$ $(\mathrm{Fe}, \mathrm{Mn})^{3+}(\mathrm{Nb}, \mathrm{Ta})$ direction, indicating that ixiolite may contain some $\mathrm{Fe}^{3+}$. The fact that the totals of cations normalized to 2 atoms of oxygen do not generally exceed 1 in most of the ixiolite analyses would indicate that the $\mathrm{Fe}^{3+}$ contents are very low (Neiva 1996). Nevertheless, the ixiolite composition could also have been controlled by another substitution mechanism, as is seen in the 
triangular diagram, below the data corresponding to the field of the columbite-group minerals, $(\mathrm{Nb}, \mathrm{Ta})_{4} \mathrm{Fe}_{-1} \mathrm{~W}_{-3}$, (Fig. 7a). This suggests that $\mathrm{W}$ was incorporated in the ixiolite structure by a wolframite-type substitution. The higher the $\mathrm{W}$ contents are (exceeding significantly those of $\mathrm{Sn}$ ), the more pronounced the deviation to the join $(\mathrm{Nb}, \mathrm{Ta})_{4} \mathrm{Fe}_{-1} \mathrm{~W}_{-3}$, as described by Suwinonprecha et al. (1995) and Neiva (1996).

Furthermore, a negative correlation between $\mathrm{Nb}$ and $\mathrm{Ta}$ can be observed (Fig. 7b), although both these elements are partially replaced by Ti (Fig. 7c) and W (no shown). Similar compositional variation has been described for the Ti-rich ixiolite exsolutions hosted by cassiterite in quartz veins of the Fental and Muralha deposits, Portugal (Neiva 1996).

\subsubsection{Rutile}

The high potential of rutile as a geochemical indicator in many hydrothermal deposits has been attributed to its common presence as accessory mineral and its capacity to accommodate a large variety of substitutions by major and trace elements: e.g. $\mathrm{Fe}, \mathrm{Cr}, \mathrm{V}, \mathrm{Nb}$ and $\mathrm{Ta}$ (Clark and Williams-Jones 2009). Thus, for example, rutile associated with granite-related tin deposits typically displays high Sn and W contents, whereas that occurring in granitic pegmatites contains $\mathrm{Nb}$ and $\mathrm{Ta}$ in addition.

Oscillatory zoning of the rutile II occurring in the mineralized quartz veins of the Jálama Batholith is interpreted as a consequence of variations in Ti concentrations, due to the variable substitution of $\mathrm{Ti}$ by $\mathrm{Nb}, \mathrm{Ta}$, $\mathrm{Fe}$ and $\mathrm{W}$. In contrast to the ixiolite, $\mathrm{Nb}$ and Ta show a positive correlation in the rutile I and II samples (Fig. $7 \mathrm{~b})$. However, both ixiolite and rutile display a very good negative correlation between $\mathrm{Nb}+\mathrm{Ta}$ and Ti (Fig. 7c). This would suggest that similar amounts of $\mathrm{Nb}$ and $\mathrm{Ta}$ entered the rutile structure, especially of rutile II, to replace Ti, whereby Ta contents are usually slightly higher (Tab. 3). The incorporation of $\mathrm{Nb}, \mathrm{Ta}$ and $\mathrm{Fe}$ into rutile II corresponds to a $\mathrm{Ti}_{3}(\mathrm{Fe}, \mathrm{Mn})^{2+}{ }_{-1}(\mathrm{Nb}, \mathrm{Ta})_{-2}$ columbite-type substitution, since the rutile data plot along the (Sn,Ti) $(\mathrm{Fe}, \mathrm{Mn})(\mathrm{Nb}, \mathrm{Ta})_{2}$ join in the same way as ixiolite and cassiterite do (Fig. 7a). However, the variations in charges owing to the presence of $\mathrm{Fe}^{2+}$ and $\mathrm{W}^{6+}$ require a coupled substitution in order to maintain the electro-neutrality. This additional substitution might be represented by a $2 \mathrm{Ti}^{4+} \leftrightarrow \mathrm{Fe}^{2+}+\mathrm{W}^{6+}$ vector (Rice et al. 1998).

Fluctuations in activity of the components involved (Černý et al. 2007a) in the crystallization of $\mathrm{Nb}$-Ta-rich rutile II have been proposed to have caused the oscillatory zoning observed in all samples from the Jálama quartz veins. Different diffusion rates of $\mathrm{Fe}, \mathrm{Mn}, \mathrm{Nb}$ and $\mathrm{Ta}$ are to be expected along the growth surfaces of the rutile, as in other deposits where rutile crystallized with a similar oscillatory zoning. However, W does not behave in the same way, failing to define oscillatory zoning patterns in rutile (Carruzzo et al. 2006; Černý et al. 2007a). Moreover, the low $\mathrm{Zr}$ contents in the rutile II support the conclusions by Černý et al. (2007b) concerning the limited possibility of this element to enter the of niobian rutile.

The rutile crystals studied in the granites, aplites and pegmatite bodies of the Jálama Batholith commonly contain significant $\mathrm{Al}$ in their lattice (Llorens and Moro 2012b). As shown in Tab. 3, rutile I in the quartz veins of the Salmantina Group was able to accommodate up to 1.33 wt. $\% \mathrm{Al}_{2} \mathrm{O}_{3}$, whereas several samples of rutile II reached even 3.34 wt. $\% \mathrm{Al}_{2} \mathrm{O}_{3}$. The incorporation of $\mathrm{Al}$ into the rutile structure was probably compensated by oxygen vacancies through the $\mathrm{Al}_{2} \square \mathrm{Ti}_{-2} \mathrm{O}_{-1}$ substitution mechanism (Hata et al. 1996). Even though rutile containing up to 9 wt. $\% \mathrm{Al}_{2} \mathrm{O}_{3}$ has been synthesized in the laboratory from peraluminous melts (Horng et al. 1999), these experiments were not conducted under realistic geologic conditions (the parental melt contained $\mathrm{Si}, \mathrm{Al}, \mathrm{K}, \mathrm{Ti}$, $\mathrm{Nb}$ and $\mathrm{Ta}$, but no Fe nor Mn to favor columbite-like substitution, as occurs in real geologic environments). The highest $\mathrm{Al}$ content so far reported in natural rutile was up to 1.2 wt. $\% \mathrm{Al}_{2} \mathrm{O}_{3}(0.019$ apfu $\mathrm{Al})$ from the highly evolved biotite granite of Podlesí (Erzgebirge, Czech Republic) and related greisens (Breiter et al. 2007). The Podlesí rutile, however, has typically low $\mathrm{Nb}, \mathrm{Ta}$ and $\mathrm{Fe}$ contents, in contrast to the rutile II from the Jálama quartz veins, which accommodate up to 0.019 apfu $\mathrm{Nb}$ and $\mathrm{Ta}$, and up to 0.034 apfu $\mathrm{Fe}$.

\subsection{Evolution of mineralization in the quartz veins}

The evolution of the ore minerals in the quartz veins of the Jálama Batholith is presented on the quadrilateral columbite diagram (Fig. 8), in which the data on wolframite I and II, rutile I and II and ixiolite are plotted. On the one hand, wolframite I from the early stage of precipitation (mostly ferberite), which is associated with cassiterite $\mathrm{I}$, shows a $\mathrm{Ta} /(\mathrm{Ta}+\mathrm{Nb})$ ratio of $0.000-0.185$ and $\mathrm{Mn} /(\mathrm{Mn}+\mathrm{Fe})$ ratio of $0.085-0.604$. On the other hand, these ratios in wolframite II (hübnerite) range between 0.000 and 0.201 , and between 0.533 and 0.704 respectively (Tab. 2). According to this, the evolutionary trend from the early $\mathrm{Sn}-\mathrm{W}$ precipitation to the main $\mathrm{Fe}-\mathrm{Zn}$ sulphide ore deposition reflects a normal evolution in the quartz veins (from Wf I to Wf II in Fig. 8). Likewise, taking into account the increasing $\mathrm{Fe}^{3+}$ contents from wolframite I to wolframite II, a major contribution of relatively oxidizing waters could be inferred (Williamson et al. 2000).

The $\mathrm{Sn}^{4+}$ of the hydrothermal fluid parental quartz veins was fixed in the crystal structure of cassiterite I 


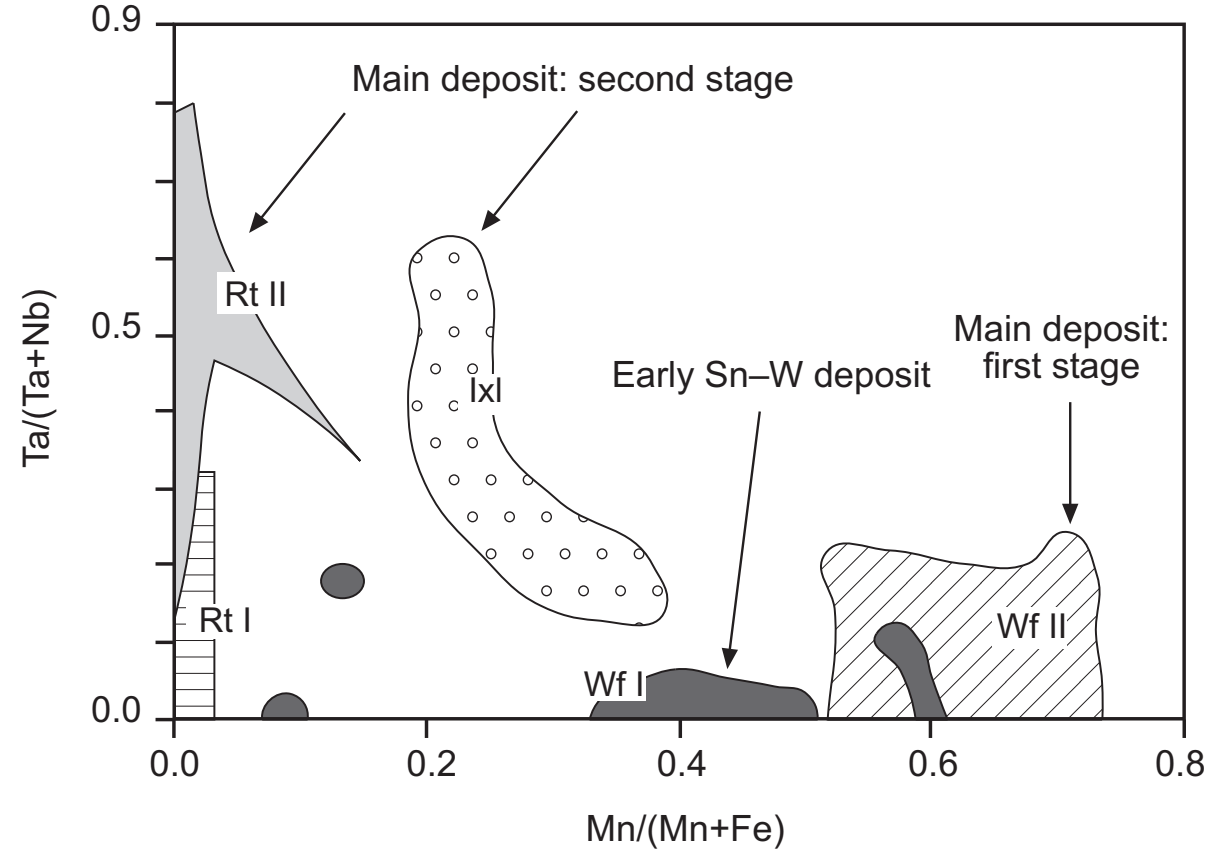

Fig. 8 Wolframite, ixiolite and rutile mineral data plotted in the columbite diagram, where two evolutionary trends can be observed: (1) a normal trend of Mn-enrichment from wolframite I (Wf I) to wolframite II (Wf II) of the main deposit in the Jálama Batholith quartz veins; and (2) a reverse trend of a Ta- and Fe-enrichment of ixiolite (Ixl) and rutile II (Rt II) of the late deposit. and II during the early stages of mineralization and the first step of the main ore deposition. However, during the second step, the amount of $\mathrm{Sn}^{4+}$ was probably below the saturation level, not permitting the cassiterite crystallization (Müller and Halls 2005). The Sn was incorporated into ixiolite and $\mathrm{Nb}$, Ta-bearing rutile II instead. The $\mathrm{Ta} /$ $(\mathrm{Ta}+\mathrm{Nb})$ and $\mathrm{Mn} /(\mathrm{Mn}+\mathrm{Fe})$ ratios in ixiolite vary from 0.148 to 0.598 , and from 0.150 to 0.365 , respectively (Tab. 3), thus plotting in intermediate areas of the quadrilateral diagram (Fig. 8). Moreover, rutile II shows a broad range of the $\mathrm{Ta} /(\mathrm{Ta}+\mathrm{Nb})$ ratios $(0.166-0.770)$ with low Mn concentrations, thus plotting very close to the vertical axis in the columbite diagram (Fig. 8).

The hydrothermal evolution of ore minerals in the quartz veins of the Jálama Batholith corresponds to enrichment in $\mathrm{Ti}$ and $\mathrm{Fe}$, at the expense of $\mathrm{Mn}$, from the crystallization of wolframite II to rutile II. The strong increase in Fe during the second episode of the main ore deposition, indicated by the crystallization of ixiolite and rutile II, suggests open-system conditions and an influence of relatively oxidizing fluids (Williamson et al. 2000). Thus, crystallization of ixiolite and rutile II after wolframite II (Fig. 8) represents an inverse evolutionary trend in comparison with the normal Mn and Ta enrichment of $\mathrm{Nb}-\mathrm{Ta}$ oxides during melt fractionation (Tindle and Breaks 1998; Beurlen et al. 2008). Analogous inverse trend has been described, for example, from the Quintos pegmatite, Borborema Province, NE Brazil (Beurlen et al. 2008).

However, this anomalous evolutionary trend would have not been complete, since increasing Ta contents are observed for the crystallization from ixiolite to rutile II
(Fig. 8). The high Ti contents of several ixiolite crystals suggest the simultaneous crystallization of ixiolite and rutile II at low temperatures (Černý et al. 1998). Taking into account the lack of replacement textures of ixiolite by rutile II, together with the presence of more or less planar growth surfaces between these minerals, the oscillatory compositional zoning parallel to the growth surfaces could be considered as a primary texture responding to changes in the mineralizing fluid composition. This might be a consequence of the mixing of the hydrothermal fluid with metamorphic and/or meteoric fluids enriched in Ti and $\mathrm{Fe}$, probably induced by variations in pressure and temperature (Müller and Halls 2005). Such fluid contamination, which is supported by preliminary data on fluid inclusions and stable isotopes in the quartz veins (Llorens 2011), might also have caused the textural variability of rutile II (e.g. oscillatory zoning, patchy textures).

\subsection{Incorporation of Ti, Nb and Ta: the role of volatiles}

The natural development of peraluminous systems, as in the case of the Jálama granitic cupola in the Navasfrías district, is to evolve towards an enrichment in volatiles, such as $\mathrm{F}, \mathrm{Cl}$ and/or $\mathrm{B}$, due to the fractionation of the melts. Thus, the residual melts show very low viscosity owing to their high contents of volatiles, especially $\mathrm{F}$ (Dingwell et al. 1985; London 1987; Webster and Holloway 1990; Giordano et al. 2004). Moreover, volatiles have been demonstrated to have a strong influence on the activity of the trace elements present in the melts, since 
they increase the solubility of the high-field strength elements (Keppler 1993).

Fluorine is a major constituent of the fluids related to Sn-bearing granites (Barsukov and Sushchevskaya 1973; Eadington 1983), playing an important role in the alteration sequence of the original granitic rock. According to Pollard (1983), the F enrichment in a Narich residual melt, such as that which could resulted from the fractional crystallization of the Jálama granitic cupola, would have induced a sodium metasomatism during post-magmatic stages in response to increasing $\mathrm{pH}$ and $a \mathrm{HF}$. The increasing acidity led mainly to the destabilization of potassic feldspar and, less so, of mica and plagioclase. Thus, albitization processes could have become widespread along the northern margin of the Jálama Batholith, affecting especially the peri-batholithic pegmatite dikes of Cruz del Rayo (Llorens and Moro 2012b). Subsequently, greisenization sensu stricto would have promoted the replacement of the minerals forming pegmatite dikes with a typical quartz + muscovite assemblage. The greisenization processes were caused by an increase in the concentration of volatiles, which acidified the environment (Burt 1981). During, and after the greisenization, silicification processes continued (Pirajno 1992), which could have developed the systems of mineralized quartz veins associated to the granites with mineralization potential: the granitic facies of the External Unit (Ruiz et al. 2008).

Titanium has been considered to be one of the less mobile elements during hydrothermal processes, since it tends to create non-volatile ionic compounds of limited capability of migration through silicate melts when an alteration of magmatic minerals takes place. A similar behavior is seen in pure aqueous fluids, corroborating the poor mobility of Ti (Ayers and Watson 1993; Audétat and Keppler 2005; Tropper and Manning 2005; Antignano and Manning 2008; Manning et al. 2008). However, addition of $\mathrm{F}$ to the fluid would increase Ti solubility up to 100 -fold in comparison with the pure aqueous fluid (Rapp et al. 2010). Moreover, Na plays an important role in $\mathrm{Ti}$ mobility because albite-saturated fluids display high HF contents (Antignano and Manning 2008).

Considering that $\mathrm{Ti}$ is a compatible element that is commonly fixed by magmatic minerals, two possibilities can be proposed to explain its incorporation into the hydrothermal system. The first one is the muscovitization of the magmatic minerals containing $\mathrm{Ti}$, such as biotite. As suggested by Llorens and Moro (2012b), the same process could have played an important role in releasing elements such as $\mathrm{Sn}, \mathrm{Nb}$ and $\mathrm{Ta}$, which were fixed in trace amounts in the structures of muscovite and biotite from the granitic facies of the External Unit. Muscovitization of biotite would have favored the incorporation of part of the released Ti to rutile and ilmenite, whereas the rest would have escaped to the exsolved fluids responsible for the later mineralization. The mobility of Ti up to these late stages of deposition should be favored by $\mathrm{Na}$ saturation of the residual melts, since the latter show high HF contents (Antignano and Manning 2008). This scheme is in agreement with the conclusions obtained by Fernández-Leyva (2007) and Ruiz et al. (2008), who established that the granitic facies of the External Unit had high mineralization potential, thus favoring the precipitation of disseminated $\mathrm{Sn}-, \mathrm{Nb}$ - and Ta-bearing minerals in the granites and the concentration of such elements, together with $\mathrm{W}$, towards the last hydrothermal fluids to form the mineralized quartz veins.

The second possibility invokes a contamination by circulating hydrothermal fluids coming from the host metamorphic rocks. This influx of external fluids would not only contribute $\mathrm{Ti}$, but also elements such as $\mathrm{Mg}, \mathrm{Ca}$, $\mathrm{Sr}$ and $\mathrm{Ba}$ (Llorens and Moro 2012a). Bearing in mind that these elements are commonly compatible, and thus preferentially incorporated into minerals during the magmatic stage, their presence in the later depositional events may point to a contamination by fluid expelled from the host metamorphic rocks. This contamination is also supported by the preliminary data on the fluid inclusions and the stable isotopes studies (Llorens 2011).

In the Jálama Batholith, a combination of both processes, muscovitization of biotite and contamination by metamorphic fluids, could have promoted the mobilization of $\mathrm{Ti}$ together with other compatible elements and their entry to the structure of cassiterite, rutile and ixiolite. This is evident from the early ore deposition, where cassiterite I crystallized with high contents in Ti and was associated with $\mathrm{Mg}$ - and Ca-bearing phosphates, such as triplite (Llorens and Moro 2012a).

The solubility of Ti depends on the chemical composition of the fluids, as well as on $T$ and $\mathrm{pH}$. The Ti mobility at 400 to $700{ }^{\circ} \mathrm{C}$ is higher in F-rich solutions and acid environments, since Ti would form complexes with $\mathrm{F}^{-}$, $\mathrm{Cl}^{-}$and $\mathrm{OH}^{-}$(Ryzhenko et al. 2006). Consequently, in a fluid enriched in $\mathrm{F}$ and $\mathrm{Ti}$, the crystallization of $\mathrm{F}$-bearing minerals will induce the increase in Ti activity and the crystallization of rutile (Rapp et al. 2010). In the mineralized quartz veins of the Jálama Batholith, the presence of $\mathrm{F}$ in the ore fluid led to the crystallization of fluorapatite, which is present at nearly all the depositional stages in these quartz veins, and of isokite, which crystallized during the same deposition stage as rutile II and ixiolite (Llorens and Moro 2012a). Both these phosphate minerals contain high amounts of $\mathrm{F}$.

The crystallization of ixiolite with $\mathrm{Nb}$-Ta-rich rutile II would suggest a late enrichment in $\mathrm{Ti}, \mathrm{Nb}$ and $\mathrm{Ta}$ of the mineralized fluids that formed the intra-granitic quartz veins. This could be explained in terms of an increased insolubility of Ta-rich complexes as the F concentration 
rose in the fluid (Linnen 1998). Consequently, $\mathrm{Nb}$ and $\mathrm{Ta}$ entered into the ixiolite and rutile structure at later crystallization stages. Moreover, Linnen and Keppler (1997) have reported the preference of accessory minerals such as $\mathrm{Nb}$ - $\mathrm{Ta}$ oxides to incorporate more $\mathrm{Nb}$ than $\mathrm{Ta}$, as it is the case in ixiolite. Thus, the $\mathrm{Nb} / \mathrm{Ta}$ ratio progressively decreased in the residual fluid as the fractionation proceeded.

\section{Conclusions}

The mineralized quartz veins hosted by the distal granitic facies of the Jálama Batholith (Salamanca, Spain) resulted from successive processes of fractures opening and their invasion by hydrothermal fluids enriched in volatiles:

1. The early ore deposition mainly brought cassiterite I and wolframite I (ferberite), together with subordinate sulphides and rutile I.

2. After a ductile deformation, and as temperature decreased, the main $\mathrm{Fe}-\mathrm{Zn}$ sulphide mineralization was deposited from slightly oxidizing fluids, followed by smaller quantities of cassiterite II and wolframite II (hübnerite).

3. An intense fracturing took place later, which allowed the introduction of elements into the system. For instance Ti presumably came from hydrothermal fluids expelled from the host metamorphic rocks, rich in $\mathrm{F}$ and P. The crystallization of $\mathrm{Fe}-, \mathrm{Mn}-, \mathrm{Mg}$ - and Ca-bearing phosphates, such as isokite and fluorapatite, extracted $\mathrm{F}$ from the hydrothermal fluid, favoring saturation in $\mathrm{Ti}, \mathrm{Nb}$ and Ta. This induced the crystallization of ixiolite and $\mathrm{Nb}$,Ta-rich rutile II, filling fractures in previous minerals during the second step of the main ore deposition.

4. Finally, quartz and carbonates filled open spaces and cavities of the quartz veins.

Acknowledgements. This study was supported by the Comunidad Autónoma de Castilla y León (Research Project Ref. SA015A06 and Research Fellowship). Thanks are due to Miguel Ángel Fernández for performing electronmicroprobe analyses and providing BSE images and the general assistance during the analytical work. The authors gratefully acknowledge M. Novák for his editorial handling, as well as Z. Johan and A. Lima for their critical reviews and valuable improvements of the manuscript.

\section{References}

Amichba TM, Dubakina LS (1974) "Wolframoixiolite" in ores of tungsten deposits of Yakutia. Sborn Nauchn Trud Mosk Otdel Vses Mineral Obshch 1974, pp 11-18 (in Russian)
Antignano A, Manning CE (2008) Rutile solubility in $\mathrm{H}_{2} \mathrm{O}$, $\mathrm{H}_{2} \mathrm{O}-\mathrm{SiO}_{2}$, and $\mathrm{H}_{2} \mathrm{O}-\mathrm{NaAlSi}_{3} \mathrm{O}_{8}$ fluids at $0.7-2.0 \mathrm{GPa}$ and $700-1000{ }^{\circ} \mathrm{C}$ : implications for mobility of nominally insoluble elements. Chem Geol 255: 283-293

Audétat A, Keppler H (2005) Solubility of rutile in subduction zone fluids, as determined by experiments in the hydrothermal diamond anvil cell. Earth Planet Sci Lett 232: 393-402

Auriscchio C, De Vito C, Ferrini V, Orlandi P (2002) Nb and Ta oxide minerals in the Fonte del Petre granitic pegmatite dike, Island of Elba, Italy. Canad Mineral 40: 799-814

Ayers JC, Watson EB (1993) Rutile solubility and mobility in supercritical aqueous fluids. Contrib Mineral Petrol 114: $321-330$

Barsukov VL, Sushchevskaya TM (1973) On the composition evolution of hydrothermal solutions in the process of the formation of the tin ore deposits. Geokhimiya 4: 491-503 (in Russian)

Beddoe-Stephens B, Fortey NJ (1981) Columbite from the Carrock Fell tungsten deposit. Mineral Mag 44: 217-223

Beurlen H, Da Silva MrR, Thomas R, Soares DR, Olivier $\mathrm{P}$ (2008) Nb-Ta- (Ti-Sn) oxide mineral chemistry as tracer of rare-element granitic pegmatite fractionation in the Borborema Province, Northeastern Brazil. Miner Depos 43: 207-228

Bons PD (2000) The formation of veins and their microstructures. In: Jessell MW, URAI JL (eds) Stress, Strain and Structure - A volume in honour of WD Means. J Virtual Expl 2 paper 4, doi:10.3809/jvirtex.2000.00007

Breiter K, ŠKoda R, Uher P (2007) Nb-Ta-Ti-W-Sn-oxide minerals as indicators of peraluminous $\mathrm{P}$ - and F-rich granitic system evolution: Podlesí, Czech Republic. Mineral Petrol 91: 225-248

BURT DM (1981) Acidity-salinity diagrams. Application to greisen and porphyry deposits. Econ Geol 76: 832-843

Carruzzo S, Clarke DB, Pelrine KM, MacDonald MA (2006) Texture, composition and origin of rutile in the South Mountain Batholith, Nova Scotia. Canad Mineral 44: 715-729

Clark JR, Williams-Jones AE (2009) Compositional variability of rutile in hydrothermal ore deposits. Am Geophys Union Spring Meeting 2009, abstract \#V14A-01

ČERNÝ P, CHAPMAN R (2001) Exsolution and breakdown of scandian and tungstenian $\mathrm{Nb}-\mathrm{Ta}-\mathrm{Ti}-\mathrm{Fe}-\mathrm{Mn}$ phases in niobian rutile. Canad Mineral 39: 93-101

ČERNÝ P, ERCIT S (1985) Some recent advances in the mineralogy and geochemistry of $\mathrm{Nb}$ and $\mathrm{Ta}$ in rare-element granitic pegmatites. Bull Minéral 108: 499-532

ČERNÝ P, ERCIT S (1989) Mineralogy of niobium and tantalum: crystal chemical relationships, paragenetic aspects and their economic implications. In: MölLER P, ČERNÝ P, SAupé F (eds) Lanthanides, Tantalum and Niobium. 
SGA Special Publications 7: Springer-Verlag, New York, pp 27-29

ČERNÝ P, ERCIT TS (2005) The classification of granitic pegmatites revisited. Canad Mineral 43: 2005-2026

Černý P, MeintZer RE, Anderson AJ (1985) Extreme fractionation in rare-element granitic pegmatites: selected examples of data and mechanism. Canad Mineral 23: 381-421

Černý P, Goad BE, Hawthorne C, Chapman R (1986) Fractionation trends of the $\mathrm{Nb}$ - and Ta-bearing oxide minerals in the Greer Lake pegmatitic granite and its pegmatite aureole, southeastern Manitoba. Amer Miner 71: 501-517

ČERnÝ P, ERCIT TS, Wise MA, Chapman R, Buck M (1998) Compositional, structural and phase relationships in titanian ixiolite and titanian columbite-tantalite. Canad Mineral 36 574-561

Černý P, Novák M, Chapman R, Ferreira K (2007a) Subsolidus behavior of niobian rutile from the Písek region, Czech Republic: a model for exsolution in $\mathrm{W}$ - and $\mathrm{Fe}^{2+}$ >> $\mathrm{Fe}^{3+}$-rich phases. J Geosci 52: 143-159

Černý P, Ercit TS, Smeds S-A, Groat LA, Chapman R (2007b) Zirconium and hafnium in minerals of the columbite and wodginite groups from granitic pegmatites. Canad Mineral 45: 185-202

Dingwell DB, Scarfe CM, Cronin DJ (1985) The effect of fluorine on the viscosities of melts in the system $\mathrm{Na}_{2} \mathrm{O}-$ $\mathrm{Al}_{2} \mathrm{O}_{3}-\mathrm{SiO}_{2}$ : implications for phonolites, trachytes and rhyolites. Amer Miner 70:80-87

EADINGTON PJ (1983) A fluid inclusion investigation of ore formation in a tin-mineralized granite, New England, New South Wales. Econ Geol 78: 1204-1221

Ercit TS, ČERnÝ P, Hawthorne FC, McCammon CA (1992) The wodginite group. II. Crystal chemistry. Canad Mineral 30: 613-631

Fernández-Leyva C (2007) Metallogenetic Study of the Jálama Batholith and Surroundings. Unpublished Ph.D. thesis, Universidad Politéctnica de Madrid, Madrid, pp 1-188 (in Spanish)

Giordano D, Romano C, Poe B, Dingwell, DB, Behrens $\mathrm{H}$ (2004) The combined effects of wáter and fluorine on the viscosity of silicic magmas. Geochim Cosmochim Acta 68: 5159-5168

Giuliani G (1987) La cassitérite zone du gisement de Sokhret Allal (Granite des Zaër; Maroc Central): composition chimique et phases fluides associées. Miner Depos 22: 253-261

GouANVIC Y, BABKINE J (1985) Metallogenie du gisement à tunstène-etain de Monteneme (N.W. Galice, Espagne). Miner Depos 20: 8-15

Groves DJ, BaKer WE (1972) The regional variation in composition of wolframites from Tasmania. Econ Geol 67: $362-368$

HAAPALA I (1997) Magmatic and postmagmatic processes in tin-mineralized granites: topaz-bearing leucogranite in the Eurajoki Rapakivi Granite Stock, Finland. J Petrol 38: $1645-1659$

Hata K, Higuchi M, Takahashi J, Kodaira K (1996) Floating zone growth and characterization of aluminiumdoped rutile single crystals. J Cryst Growth 163: 279-284

Horng W-S, Hess PC, Gan H (1999) The interaction between $\mathrm{M}^{+5}$ cations $\left(\mathrm{Nb}^{+5}, \mathrm{Ta}^{+5}\right.$, or $\left.\mathrm{P}^{+5}\right)$ and anhydrous haplogranite melts. Geochim Cosmochim Acta 63: 2419-2428

JoHan V, Johan Z (1994) Accessory minerals of the Cínovec (Zinnwald) granite cupola, Czech Republic. Part 1: Nb-, Ta- and Ti-bearing oxides. Mineral Petrol 51: 323-343

KEPPLER H (1993) Influence of fluorine on the enrichment of high field strength trace elements in granitic rocks. Contrib Mineral Petrol 114: 479-488

Lerouge C, Deschamps Y, Piantone P, Gilles C, Breton J (2007) Metal-carrier accessory minerals associated with $\mathrm{W} \pm \mathrm{Sn}$ mineralization, La Châtaigneraie tungsten ore district, Massif Central, France. Canad Mineral 45: 875-889

LinNEN RL (1998) The solubility of Nb-Ta-Zr-Hf-W in granitic melts with $\mathrm{Li}$ and $\mathrm{Li}+\mathrm{F}$ : constraints for mineralization in rare metal granites and pegmatites. Econ Geol 93: 1013-1025

LinNen RL, KePpleR H (1997) Columbite stability in granitic melts: consequences for the enrichment and fractionation of $\mathrm{Nb}$ and $\mathrm{Ta}$ in the Earth crust. Contrib Mineral Petrol 128: $213-227$

Llorens T (2011) The Sn-W-(Nb-Ta) Magmatic-Hydrothermal Mineralizations of the Navasfrías District (SW Salamanca). Ph.D. thesis, Salamanca University. Vítor Collection 290: pp 1-353. ISBN 978-84-7800-088-3 (in Spanish)

Llorens T, Moro MC (2007) Preliminary study of intragranitic pegmatites in the $\mathrm{Sn}-\mathrm{W}-(\mathrm{Au})$ district of Navasfrías (SW of Salamanca, Spain). In: Martins T, VIEIRA R (eds) Granitic Pegmatites: the State of the Art, Book of Abstracts. Universidad do Porto, Department of Geology, Porto, Memórias 8: 56-57

Llorens T, Moro MC (2008) Al-Fe-Mn phosphates in the intra-granitic pegmatites of the Navasfrías district (SW Salamanca). In: Delgado J, Astilleros JM, Bauluz B, Calvo B, González I, Herrero JM, López J, Proenza J, Rodríguez C (eds) XXVIII Reunión de la Sociedad Española de Mineralogía, XXI Reunión de la Sociedad Española de Arcillas. Sociedad Española de Mineralogía, Macla 9: 145-146 (in Spanish)

Llorens T, Moro MC (2010a) Microlite and tantalite in the LCT granitic pegmatites of La Canalita, Navasfrías Sn-W District, Salamanca, Spain. Canad Mineral 48: 549-564

Llorens T, Moro MC (2010b) Columbite-group minerals in the Cruz del Rayo pegmatite dikes, SW Salamanca, Spain. In: Pál-Molnár E, Árkai P, Buda G, Dódony I, 
Fancsik T, Földessy J, Harangi S, Hetényi M, Koroknai B, Tóth TM, Papp G, Pósfai M, Rózsa P, Sipos P, Szabó C, Szakáll S, Szederkényi T, Viczián I, Zelenka T (eds) IMA 2010, Bonds and Bridges, CD of Abstracts. Department of Mineralogy, Geochemistry and Petrology, University of Szeged. Acta Mineral Petrogr, Abstr Ser, Szeged 6: 167

Llorens T, Moro MC (2010c) Nb-Ta-oxide minerals in the LCT pegmatites of La Canalita, SW Salamanca, Spain. In: PÁl-Molnár E, Árkai P, Buda G, Dódony I, FancSik T, Földessy J, Harangi S, Hetényi M, Koroknai B, Tóth TM, Papp G, Pósfai M, Rózsa P, Sipos P, Szabó C, SzakÁll S, Szederkényi T, Viczián I, Zelenka T (eds) IMA 2010, Bons and Bridges, CD of Abstracts. Budapest, Department of Mineralogy, Geochemistry and Petrology, University of Szeged. Acta Mineral Petrogr, Abstr Ser, Szeged 6: 167

Llorens T, Moro MC (2012a) Fe-Mn phosphate associations as indicators of the magmatic-hydrothermal and supergene evolution of the Jálama Batholith in the Navasfrías Sn-W District, Salamanca, Spain. Mineral Mag 76: 1-24

Llorens T, Moro MC (2012b) Oxide minerals in the granitic cupola of the Jálama Batholith, Salamanca, Spain. Part $\mathrm{I}$ : accessory $\mathrm{Sn}, \mathrm{Nb}$, Ta and Ti minerals in leucogranites, aplites and pegmatites. J Geosci 57: 25-43

LONDON D (1987) Internal differentiation of rare-element pegmatites: effects on boron, phosphorus, and fluorine. Geochim Cosmochim Acta 51: 403-420

Manning CE, Wilke M, Schmidt C, Cauzid J (2008) Rutile solubility in albite- $\mathrm{H}_{2} \mathrm{O}$ and $\mathrm{Na}_{2} \mathrm{Si}_{3} \mathrm{O}_{7}-\mathrm{H}_{2} \mathrm{O}$ at high temperatures and pressures by in-situ synchrotron radiation micro-XRF. Earth Planet Sci Lett 272: 730-737

Martínez Catalán JR, Martínez Poyatos D, Bea F (2004) Centro-Iberic Zone. In: VerA JA (ed) Geology of Spain. SGE-IGME, Madrid, pp 68-133 (in Spanish)

Martins T, Lima A, Simmons S, Falster A, Noronha F (2011) Geochemical fractionation of $\mathrm{Nb}-\mathrm{Ta}$ oxides in Li-bearing pegmatites from the Barroso-Alvão pegmatite field, Northern Portugal. Canad Mineral 49: 777-791

Möller P, Dulski P, Szacki W, Malow G, Riedel E (1988) Substitution of tin in cassiterite by tantalum, niobium, tungsten, iron and manganese. Geochim Cosmochim Acta 52: 1497-1503

Moro MC, Llorens T (2008) Triplite-apatite-isokite in the $\mathrm{Sn}-\mathrm{W}$ intragranitic quartz veins of La Salmantina (Navasfrías, SW Salamanca). In: Delgado J, Astilleros JM, Bauluz B, Calvo B, González I, Herrero JM, López J, Proenza J, Rodríguez C (eds) XXVIII Reunión de la Sociedad Española de Mineralogía, XXI Reunión de la Sociedad Española de Arcillas. Sociedad Española de Mineralogía, Macla 9: 167-168 (in Spanish)

Moro MC, Villar P, Fadón O, Fernández A, Cembranos ML, Crespo JL (2001) Bismuthinite, pavonite, gustavite and lillianite homologues in the $\mathrm{Sn}-\mathrm{W}$ deposits of the Navasfrías district (SW Salamanca). Bol Soc Esp Mineral 24-A: 161-162 (abstract, in Spanish)

Müller A, Halls C (2005) Rutile - the tin-tungsten host in the intrusive tourmaline breccia at Wheal Remfry, SW England. In: Mao J, Bierlein FP (eds) Mineral Deposit Research: Meeting the Global Challenge. Proceedings of the Eighth Biennial SGA Meeting, Beijing, pp 441-444

NeIVA AMR (1996) Geochemistry of cassiterite and its inclusions and exsolution products from tin and tungsten deposits in Portugal. Canad Mineral 34: 745-768

NeIva AMR (2008) Geochemistry of cassiterite and wolframite from tin and tungsten quartz veins in Portugal. Ore Geol Rev 33: 221-238

Novák M, Johan Z, ŠKoda R, ČERnÝ P, Šrein V, Veselovský $\mathrm{F}$ (2008) Primary oxide minerals in the system $\mathrm{WO}_{3}-$ $\mathrm{Nb}_{2} \mathrm{O}_{5}-\mathrm{TiO}_{2}-\mathrm{Fe}_{2} \mathrm{O}_{3}-\mathrm{FeO}$ and their breakdown products from the pegmatite No. 3 at Dolní Bory-Hatě, Czech Republic. Eur J Mineral 20: 487-499

Pal DC, Mishra B, Bernhardt H-J (2007) Mineralogy and geochemistry of pegmatite-hosted Sn-, Ta-Nb-, and $\mathrm{Zr}-\mathrm{Hf}$-bearing minerals from the southeastern part of the Bastar-Malkangiri pegmatite belt, Central India. Ore Geol Rev 30: 30-55

PIRAJNo F (1992) Hydrothermal mineral deposits. Principles and Fundamental Concepts for the Exploration Geologist. Springer-Verlag, Heidelberg, pp 1-710

Pollard PJ (1983) Magmatic and postmagmatic processes in the formation of rocks associated with rare-element deposits. Trans Inst Min Metall 92: B1-B9

Polya DA (1988) Compositional variation in wolframites from the Barroca Grande mine, Portugal: evidence for fault-controlled ore formation. Mineral Mag 52: 497-503

RAmírez JA (1996) Petrological, Geochemical and Isotopic Study of the Jálama Batholith (North of Extremadura). Unpublished Ph.D. thesis, University of Granada, pp 1-201 (in Spanish)

Ramírez JA, Grundvig S (2000) Causes of geochemical diversity in peraluminous granitic plutons: the Jálama Pluton, Central-Iberian Zone (Spain and Portugal). Lithos 50: 171-190

Rapp JF, Klemme S, Butler IB, Harley SL (2010) Extremely high solubility of rutile in chloride and fluoride-bearing metamorphic fluids: an experimental investigation. Geology 38: 323-326

ReNÉ M, ŠKODA R (2011) Nb-Ta-Ti oxides fractionation in rare-metal granites: Krásno-Horní Slavkov ore district, Czech Republic. Mineral Petrol 103: 37-48

Rice CM, Darke KE, Still JW (1998) Tungsten-bearing rutile from the Kori Kollo gold mine, Bolivia. Mineral Mag 62: 421-429

Ruiz C, Fernández-Leyva C, Locutura J (2008) Geochemistry, geochronology and mineralisation potential of the 
granites in the Central Iberian Zone: the Jálama Batholith. Chem Erde 68: 413-429

Ryzhenko B, Kovalenko N, Prisyagina N (2006) Titanium complexation in hydrothermal systems. Geochem Int 44: 879-895

Spilde MN, Shearer CK (1992) A comparison of tantalum-niobium oxide assemblages in two mineralogically distinct rare-element granitic pegmatites, Black Hills, South Dakota. Canad Mineral 30: 719-737

SuwinonPreCha P, ČERnÝ P, Friedrich G (1995) Rare metal mineralization related to granites and pegmatites, Phuket, Thailand. Econ Geol 90: 603-615

Tindle AG, Breaks FW (1998) Oxide minerals of the Separation Rapids rare-element granitic pegmatite group, northwestern Ontario. Canad Mineral 36: 609-635

Tindle AG, Webb PC (1989) Niobian wolframite from Glen Gairn in the eastern Highlands of Scotland: a microprobe investigation. Geochim Cosmochim Acta 53: 1921-1935
Tindle AG, Breaks FW, WebB PC (1998) Wodginite-group minerals from the Separation Rapids rare-element granitic pegmatite group, northwestern Ontario. Canad Mineral 36: 637-658

Tropper P, Manning CE (2005) Very low solubility of rutile in $\mathrm{H}_{2} \mathrm{O}$ at high pressure and temperature, and its implications for Ti mobility in subduction zones. Amer Miner 90: 502-505

Webster JD, Holloway JR (1990) Partitioning of F and $\mathrm{Cl}$ between magmatic hydrothermal fluids and highly evolved granitic magmas. In: SteIn HJ, HANNAH JL (eds) Ore-Bearing Granite Systems: Petrogenesis and Mineralizing Processes. Geological Society of America Special Papers 246: 21-34

Williamson BJ, Spratt J, Adams JT, Tindle AG, Stanley CJ (2000) Geochemical constraints from zoned hydrothermal tourmalines on fluid evolution and Sn mineralization: an example from fault breccias at Roche, SW England. J Petrol 41: 1439-1453 